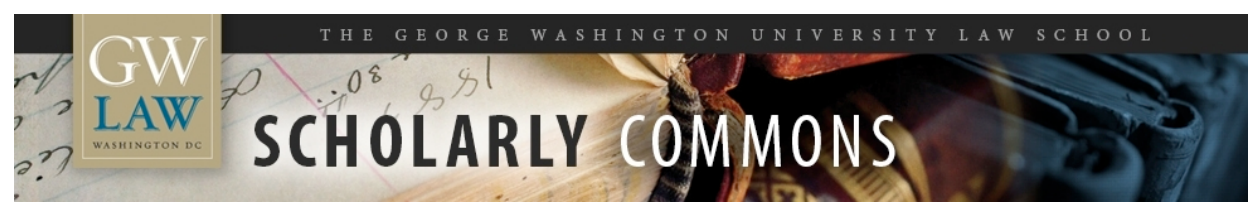

\title{
The Mystery of Unanimity in Hosanna-Tabor Evangelical Lutheran Church \& School V. EEOC
}

Ira C. Lupu

George Washington University Law School

Robert W. Tuttle

George Washington University Law School

Follow this and additional works at: https://scholarship.law.gwu.edu/faculty_publications

Part of the Law Commons

\section{Recommended Citation}

Lupu, Ira C. and Tuttle, Robert W., The Mystery of Unanimity in Hosanna-Tabor Evangelical Lutheran Church \& School v. EEOC (2017). 20 Lewis \& Clark L. Rev. 1265 (2017), in Symposium, Law and Religion in an Increasingly Polarized America; GWU Law School Public Law Research Paper No. 2017-3; GWU Legal Studies Research Paper No. 2017-3. Available at SSRN: https://ssrn.com/abstract=2830169 or http://dx.doi.org/10.2139/ssrn.2830169

This Article is brought to you for free and open access by the Faculty Scholarship at Scholarly Commons. It has been accepted for inclusion in GW Law Faculty Publications \& Other Works by an authorized administrator of Scholarly Commons. For more information, please contact spagel@law.gwu.edu. 


\title{
THE MYSTERY OF UNANIMITY IN HOSANNA-TABOR EVANGELICAL LUTHERAN CHURCH E SCHOOL V. EEOC
}

\author{
by \\ Ira C. Lupu Ẽ Robert W. Tuttle*
}

In Hosanna-Tabor Evangelical Lutheran Church \& School v. EEOC, decided in 2012, the Supreme Court held that the First Amendment supports a "ministerial exception" defense in anti-discrimination suits by clergy against their institutional religious employers. In advance of the decision, the outcome seemed unpredictable, and the Court's unanimity arrived as a shock.

This paper illuminates the result, reasoning, and unanimity in Hosanna-Tabor. We explain how Hosanna-Tabor stands in a long line of decisions, grounded in both the Establishment Clause and the Free Exercise Clause, that prohibit state adjudication of "strictly and purely ecclesiastical" questions.

Part I examines why unanimity on the Supreme Court seemed highly improbable. Other divisions on the Court in Religion Clause cases, the brooding omnipresence of Employment Division v. Smith, and the persistent feminist critique of the ministerial exception all suggested that complete agreement within the Court was unlikely. Part II focuses on the key features of Chief Justice Roberts's opinion for the Court in HosannaTabor, including the central question of which Religion Clause is doing the primary work. Part III offers our explanation and defense of the exception's jurisprudential foundation, and shows in detail how the courts - before and after Hosanna-Tabor - have steadfastly maintained that foundation and its relevant boundaries.

Part IV highlights the intense and continued division within the academy on the meaning and correctness of Hosanna-Tabor. Part IV A analyzes the work of "the Expanders," who see Hosanna-Tabor as a signifi-

* The authors are both affiliated with George Washington University. Ira C. Lupu is the F. Elwood \& Eleanor Davis Professor Emeritus of Law; Robert W. Tuttle is the David R. and Sherry Kirschner Berz Research Professor of Law and Religion. We are grateful to Axel Schamis, a member of the class of 2018 at the George Washington University Law School, for valuable assistance with research for this piece; and to Rick Garnett, Fred Gedicks, Doug Laycock and Jim Oleske for helpful comments. 
cant sign that the First Amendment protects a broad freedom of religious entities to resist general regulation. Part IV.B focuses on "the ReRationalizers," who seek to disconnect Hosanna-Tabor from religionspecific norms, and ground the ministerial exception in the freedom of association. Part IV.C turns to "the Dissenters," who argue that the ministerial exception is not required by the Constitution and is profoundly misguided. Whether designed to build up the decision or tear it down, the scholars' overstated claims about Hosanna-Tabor may resonate within the culture wars, but have no foundation in the governing law.

INTRODUCTION ................................................................... 1266

I. HOSANNA-TABOR AND UNEXPECTED JUDICIAL UNANIMITY ......... 1268

II. The Key Features of the Unanimous Opinion in Hosanna-

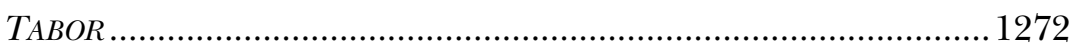

III. A DEFENSE AND Elaboration of HOSANNA-TABOR ................... 1280

IV. HOSANNA-TABOR AND Its DisconTENTS ................................ 1292

A. The Expanders-Freedom of the Church and Implied Consent

Theory ........................................................................ 1296

1. The institutionalists ......................................... 1296

2. Implied consent theorists...................................... 1299

3. Overarching problems of application .......................... 1301

B. The Re-Rationalizers_-Secular Freedom of Association............... 1304

C. The Dissenters_Feminism and the Ministerial Exception ......... 1310

CONCLUSION ..................................................................... 1314

\section{INTRODUCTION}

[After oral argument and before decision in Hosanna-Tabor], neither side could confidently count to five .... [N]o one who heard the oral argument would have predicted unanimity. ${ }^{1}$

Professor Douglas Laycock

This Symposium's theme of polarization on issues of law and religion evokes an image of a deeply and irrevocably divided Supreme Court, mirrored in a comparable split in the legal academy. The recent decisions in Burwell v. Hobby Lobby Stores, Inc. ${ }^{2}$ and Town of Greece v. Galloway ${ }^{3}$ perfectly

1 Douglas Laycock, Hosanna-Tabor and the Ministerial Exception, 35 Harv. J.L. \& Pub. Pol'y 840, 859 (2012). Professor Laycock represented Hosanna-Tabor in the U.S. Supreme Court. He was the principal author of its Supreme Court brief and presented the oral argument on its behalf.

2134 S. Ct. 2751 (2014).

3 134 S. Ct. 1811 (2014). 
embody that image. Both produced 5-4 decisions from the Court, and strenuous disagreement among legal scholars. ${ }^{4}$

At times, however, outliers from the normal pattern offer more revealing insights than the typical left-right split. Hosanna-Tabor Evangelical Lutheran Church E School v. EEOC $C^{5}$ presents a perfect opportunity for reflection on the significance of a decision that departs from the usual story. In Hosanna-Tabor, the Justices unanimously declared both the existence and broad scope of a ministerial exception to laws regulating some employment relationships in religious institutions. ${ }^{6}$ As canvassed in Part IV below, scholars have offered an incredibly wide range of views, from broad expansion to utter repudiation, of the ministerial exception. Despite the plausibility of many positions within that scholarly range, the Justices nevertheless adhered to a longstanding principle, and agreed completely on a series of essential points and supporting reasons.

This paper interrogates the meaning of that unanimity, and seeks to explain why so many scholars refuse to accept the principle that explains it. Hosanna-Tabor stands in a long line of decisions, grounded primarily in the Establishment Clause, that prohibit state adjudication of "strictly and purely ecclesiastical" "questions. Part I explores the litigation in HosannaTabor as it appeared on the eve of decision, and examines why eventual unanimity on the Supreme Court seemed so unlikely. The brooding omnipresence of Employment Division v. Smith, ${ }^{8}$ and the persistent feminist

${ }^{4}$ With respect to Hobby Lobby, compare Kevin Walsh, Symposium: Looking Forward from the Supreme Court's Important but Unsurprising Hobby Lobby Decision, SCOTUSbLOG (July 1, 2014), http://www.scotusblog.com/2014/07/symposium-looking-forward-fromthe-supreme-courts-important-but-unsurprising-hobby-lobby-decision/, with Ira Lupu \& Robert Tuttle, Symposium: Religious Questions and Saving Constructions, SCOTUSblog (Feb. 18, 2014), http://www.scotusblog.com/2014/02/symposium-religious-questionsand-saving-constructions. With respect to Town of Greece, compare Richard Garnett, Symposium: Religious Pluralism, Civic Unity, and the Judicial Role, SCOTUSblog (May 8, 2014), http://www.scotusblog.com/2014/05/symposium-religious-pluralism-civic-unityand-the-judicial-role, with Erwin Chemerinsky, Symposium: Dismantling the Wall That Should Separate Church and State, SCOTUSblog (May 6, 2014), http://www.scotusblog. com/2014/05/symposium-dismantling-the-wall-that-should-separate-church-and-state/.

${ }^{5}$ Hosanna-Tabor Evangelical Lutheran Church \& Sch. v. EEOC, 565 U.S. 171 (2012).

${ }^{6}$ Justice Alito, joined by Justice Kagan, authored a concurring opinion, urging sensitivity to the varieties of titles and roles among faith communities in the designation of those with responsibility for teaching the faith. Hosanna-Tabor, 565 U.S. at 188-89 (Alito, J., concurring). Justice Thomas wrote a separate concurring opinion, urging deference to religious entities in the designation of which employees fell within the ministerial exception. Id. at 196-97 (Thomas, J., concurring). Nevertheless, all nine Justices joined in full the Court opinion, authored by Chief Justice Roberts.

7 Watson v. Jones, 80 U.S. (13 Wall.) 679, 733 (1871).

${ }^{8} 494$ U.S. 872 (1990). 
critique of the ministerial exception, were most prominent among the reasons for expected division on the Court.

Part II focuses on the key features of Chief Justice Roberts's opinion for the Court in Hosanna-Tabor, including the question of which Religion Clause better supported the exception, and the place of Smith in understanding the Free Exercise component of the case. Part III offers our explanation of the dominant jurisprudential foundation of the exception, and shows how the Supreme Court and lower courts have steadfastly maintained that foundation and its relevant boundaries.

Part IV examines the work of other scholars, whom we divide into several basic camps, on the subject of the ministerial exception. Part IV.A. analyzes the work of the "Expanders," a group of scholars who see Hosanna-Tabor as a significant sign that the First Amendment protects a broad immunity of religious entities from general regulation. Part IV.B. focuses on the "Re-Rationalizers," who seek to disconnect Hosanna-Tabor from religion-specific norms, and to ground the ministerial exception in a general freedom of association, expressive or relational. Part IV.C. turns to the "Dissenters," who argue that the ministerial exception in general, and Hosanna-Tabor in particular, are profoundly misguided. We hope the paper illuminates the reasons for continued polarization within the academy on a question that the Court's unanimous opinion should have put to rest.

\section{HOSANNA-TABOR AND UNEXPECTED JUDICIAL UNANIMITY}

If the work of lower courts were a perfect guide to Supreme Court outcomes, no one would have been shocked at a unanimous ruling in support of a ministerial exception. ${ }^{9}$ Virtually every federal appellate circuit, and every state supreme court that had confronted the question, recognized the proposition that the Religion Clauses insulate religious entities from certain causes of action by employees primarily responsible for communicating the faith. ${ }^{10}$ Many of the cases involve claims of employment discrimination, including matters of race, and many decisions extend the boundaries of the ministerial exception beyond those who serve in conventional roles as clergy in houses of worship. ${ }^{11}$ Even after the

9 The Court might have divided over questions about whether Perich's position qualified for the exception, but not over the basic question of whether the Constitution required a ministerial exception in at least some instances.

${ }^{10}$ The federal court of appeals decisions are cited in Hosanna-Tabor, 565 U.S. at 188 n.2. We collect a number of the state decisions in Ira C. Lupu \& Robert W. Tuttle, Courts, Clergy, and Congregations: Disputes Between Religious Institutions and Their Leaders, 7 Geo. J.L. \& Pub. PoL'y 119, 127 n.51 (2009).

${ }^{11}$ Lupu \& Tuttle, supra note 10 , at 127 n.53. 
1990 decision in Employment Division v. Smith, that consistent pattern in the state and lower federal courts did not change in the slightest. ${ }^{12}$

Nevertheless, as expressed by Professor Laycock in the quote with which we begin this Article, the uncertainty across the academy about how the Supreme Court would treat the ministerial exception was widespread. The reasons are not difficult to understand. First, the Court had never expressed a view on the ministerial exception as such. The idea of a ministerial exception first appeared in the law in the Fifth Circuit's decision in McClure v. Salvation Army ${ }^{13}$ and in the ensuing 40 years the Supreme Court never made any explicit reference to the exception. ${ }^{14}$

Second, although Employment Division v. Smith had distinguished several cases involving disputes over church property and personnel ${ }^{15}$ Smith cut hard against any notion that the Free Exercise Clause supported religion-based exemptions from generally applicable laws. The civil rights laws of the United States, and of the states, certainly fit the mode of generally applicable laws, so Smith invited doubt about the ministerial exception.

Third, building on this broad understanding of Smith, the United States had argued Hosanna-Tabor on the explicit premise that federal constitutional law did not support a general ministerial exception from civil rights laws. ${ }^{16}$ The government argued that Smith's reference to "controversies over religious authority" did not extend to application of the civil rights laws to a religious employer. ${ }^{17}$ In accord with the view of some of the Re-Rationalizers, discussed below, the United States contended that the constitutional immunity for religious employers was coextensive with and bounded by the freedom of expressive association, held by secular and religious employers alike. ${ }^{18}$ Thus, a unanimous opinion in support of a ministerial exception would require every Justice to reject the

${ }^{12}$ In EEOC v. Catholic Univ. of Am., 83 F.3d 455 (D.C. Cir. 1996), the D.C. Circuit directly confronted the question of whether Smith had undermined the ministerial exception, and concluded that it had not. Id. at 461-63 (analyzing the ministerial exception as a "hybrid right" that survives Smith and involves both Free Exercise and Establishment Clause considerations).

${ }^{13} 460$ F.2d 553, 560-61 (5th Cir. 1972).

14 Serbian E. Orthodox Diocese v. Milivojevich, 426 U.S. 696 (1976), a decision concerning the dismissal of a high-ranking official of the Serbian Eastern Orthodox Diocese in North America, might have invoked the exception, but it was at that time a very recent doctrinal label in the federal courts.

${ }_{15} 494$ U.S. 872, 877 (1990) (characterizing Milivojevich, 426 U.S. at 696, Presbyterian Church v. Mary Elizabeth Blue Hull Mem'l Presbyterian Church, 393 U.S. 440 (1969), and Kedroff v. St. Nicholas Cathedral of the Russian Orthodox Church, 344 U.S. 94 (1952) as involving "controversies over religious authority or dogma").

${ }_{16}$ See Brief for Respondent at 19-29, Hosanna-Tabor Evangelical Lutheran Church \& Sch. v. EEOC, 565 U.S. 171 (2012) (No. 10-533), 2011 WL 3319555.

${ }^{17} I d$. at 22-26.

${ }^{18} I d$. at 29-32. 
view of the United States that religious employers deserved no constitutionally distinctive treatment.

Fourth, the facts of Hosanna-Tabor were significantly suboptimal from the employer's perspective. Cheryl Perich, the employee whose termination was at issue, was a "called" elementary school teacher, ${ }^{19}$ but she was not an ordained pastor who led Sabbath worship services or had the authority to administer sacraments. Religious teaching was a regular but quantitatively quite limited part of her job. Although Perich's complaint to the EEOC asserted that she was being discriminated against on grounds of disability, ${ }^{20}$ Hosanna-Tabor Evangelical Lutheran Church \& School ("Hosanna-Tabor") ultimately dismissed her in retaliation for making a complaint to a government agency. ${ }^{21}$ The EEOC's case thus rested on the prohibition on retaliation against employees who complain of forbidden discrimination, even if their own complaint of discrimination turns out to be nonmeritorious, as Perich's disability claim eventually did.

Professor Laycock's prospective assessment that, from HosannaTabor's perspective, "the case had some good facts and some bad facts,",2 thus seems entirely reasonable. Good and bad in this context reflect nothing more than the likelihood of persuading Justices to one's side. Cases with a rich mix of good-and-bad facts do not usually present a substantial likelihood of a unanimous opinion, especially in a legal context in which fact-bound analyses are commonplace. On this set of facts, the Sixth Circuit had concluded that Perich was not a "ministerial" employee, because her religious duties were not the primary focus of her job, quantitatively significant, or any different from religious duties assigned to lay teachers in the school. ${ }^{23}$ This result in the Sixth Circuit, and the mixture of facts that produced it, considerably diminished the probability of a unanimous decision, especially one in favor of her employer.

Fifth, the most likely reservation or concern in the Supreme Court about the ministerial exception was the gender-based impact of such a rule. The case itself involved a female employee. Although not all ministerial exception cases involve female employees and assertions of gender

${ }^{19}$ Hosanna-Tabor, 565 U.S. at 191 (explaining the training and commitment required to be a "called" teacher).

${ }^{20}$ Id. at 179 .

${ }^{21}$ Id. at 180.

${ }^{22}$ Laycock, supra note 1, at 840. See also Frederick Mark Gedicks, Narrative Pluralism and Doctrinal Incoherence in Hosanna-Tabor, 64 Mercer L. REv. 405, 408-13 (2013) [hereinafter Gedicks, Narrative Pluralism and Doctrinal Incoherence] (analyzing facts closely and concluding that they show "the ministerial exception deployed as a pretextual smokescreen to hide classic disability discrimination and retaliation prohibited by the ADA").

${ }^{23}$ EEOC v. Hosanna-Tabor Evangelical Lutheran Church \& Sch., 597 F.3d 769, 779-80 (6th Cir. 2010), rev'd, 565 U.S. 171 (2012). 
discrimination, a substantial number do involve that constellation of party and claim. Unsurprisingly, therefore, most of the academic criticism of the ministerial exception came from feminist scholars, ${ }^{24}$ who were concerned about sexism, both overt and covert, in the ministry of many different faiths. This concern seemed so prominently presented in this particular litigation, ${ }^{25}$ and in ministerial exception decisions more generally, that commentators assumed that Justices Ginsburg, Kagan, and Sotomayor would be influenced by it. ${ }^{26}$

Finally, the questions raised in Hosanna-Tabor presented an especially ripe opportunity for disagreement among the Justices about the scope of Employment Division v. Smith. Only two Justices who were on the Court in 1990 remained in 2012. Justice Scalia authored Smith, and Justice Kennedy joined that opinion. Three years later, Kennedy (joined by, among others, Justices Scalia and Thomas) authored the opinion in Lukumi, which explicitly reaffirmed that Smith had been correctly decided. Kennedy also authored the Smith-affirming opinion in City of Boerne ${ }^{28}$ Justices Thomas and Scalia once again joined Kennedy, as did Justice Ginsburg. So the Hosanna-Tabor Court included four Justices who had expressed open support for the correctness of Smith.

We cannot say the same of the other five, however. In City of Boerne, Justice Breyer joined Justice O'Connor's dissenting opinion, ${ }^{29}$ which asserted the incorrectness of Smith as a reason for recognizing congressional power to override that decision. ${ }^{30}$ As of 2012, Chief Justice Roberts and

${ }^{24}$ See, e.g., Joanne C. Brant, Our Shield Belongs to the Lord: Religious Employers and a Constitutional Right to Discriminate, 21 Hastings Const. L.Q. 275 (1994); Caroline Mala Corbin, Above the Law? The Constitutionality of the Ministerial Exemption from Antidiscrimination Law, 75 Fordham L. Rev. 1965 (2007); Leslie Griffin, Ordained Discrimination, The Case Against the Ministerial Exception (Univ. of Hous. Law Ctr., Paper No. 2011-A-9, 2011), http://papers.ssrn.com/sol3/papers.cfm?abstract_id=1936073; Jane Rutherford, Equality as the Primary Constitutional Value: The Case for Applying Employment Discrimination Laws to Religion, 81 Cornell L. Rev. 1049 (1966).

${ }_{25}$ See, e.g., Brief of NAACP Legal Defense Fund et al. as Amici Curiae in Support of Respondent at 4-8, Hosanna-Tabor Evangelical Lutheran Church \& Sch. v. EEOC, 565 U.S. 171 (2012) (No. 10-533), 2011 WL 3532699.

${ }^{26}$ One of the coauthors of this paper, Lupu, told a reporter at the time of oral argument that the only sure prediction in the case was that the opinion would not be for a unanimous Court, because it was unthinkable that all three female Justices would side with Hosanna-Tabor, and equally unthinkable that all six male Justices would side with the government.

${ }^{27}$ Church of the Lukumi Babalu Aye, Inc. v. City of Hialeah, 508 U.S. 520, 521 (1993).

${ }^{28}$ City of Boerne v. Flores, 521 U.S. 507, 511, 519-21 (1997) (holding that Congress may not, pursuant to the Fourteenth Amendment, impose on the states stricter religious liberty standards than the Free Exercise Clause requires).

${ }^{29}$ Id. at 544-65 (O'Connor, J., dissenting).

${ }^{30} I d$. at 544-45. 
Justice Sotomayor had offered no hints as to their views of Smith. ${ }^{31}$ Justice Alito had, while a Third Circuit judge, authored the well-known opinion in Fraternal Order of Police v. City of Newark, ${ }^{32}$ an opinion which suggested implicitly that Smith should be narrowly construed on the question of what constitutes a generally applicable law. Justice Kagan, while serving as White House Counsel in the 1990s, had strenuously criticized a state court's narrow reading of the Religious Freedom Restoration Act. ${ }^{33}$ This suggests at least a possibility that she thought Smith wrongly decided, and wanted RFRA to fill the gap in religious liberty that Smith supposedly created.

Accordingly, we can say with a fair degree of confidence that four Justices believed Smith was correct, but that the other five had views that ranged from "Smith is wrong" to some softer yet still critical view of Smith's approach to free exercise. Of course, the relevant question with respect to Hosanna-Tabor is the nexus between Smith and the ministerial exception. If, as we suggest later in this paper, Smith is utterly irrelevant to the questions posed by the ministerial exception, disagreement about Smith posed no threat to the possibility of unanimity in Hosanna-Tabor. But Smith seemed so central to the story of free exercise jurisprudence over the last 25 years that few would have expected all nine Justices to conclude that the Free Exercise Clause insulates religious entities from antidiscrimination suits by employees with ministerial duties.

\section{THE KEY FEATURES OF THE UNANIMOUS OPINION IN HOSANNA-TABOR}

Chief Justice Roberts's opinion for the full Court in Hosanna-Tabor has been the subject of elaborate commentary, ${ }^{34}$ and we will not burden the reader with repetition of the opinion's every detail. Certain aspects of

31 As noted in Professor Oleske's article in this Symposium, the Chief Justice's dissent in Obergefell v. Hodges, 135 S. Ct. 2584, 2625-26 (2015), hints at dissatisfaction with Smith. See James Oleske, Jr., A Regrettable Invitation to "Constitutional Resistance," Renewed Confusion over Religious Exemptions, and the Future of Free Exercise, 20 LEwIS \& Clark L. Rev. 1317 (2017).

${ }^{32} 170$ F.3d 359 (3d Cir. 1999). In his recent dissent from denial of certiorari in Stormans, Inc. $v$. Wiesman, Justice Alito renewed his concern with the status of religious freedom in federal constitutional law, but the focus of his dissent is on what Alito describes as the religious targeting in the Washington regulation of pharmacies, and not on the correctness of Smith. 794 F.3d 1064 (9th Cir. 2015), cert. denied, 136 S. Ct. 2433, 2434 (2016) (Alito, J., dissenting).

${ }^{33}$ The story is well told in Melissa Rogers, Free Exercise Flip? Kagan, Stevens, and the Future of Religious Freedom, Governance Stud. Brookings (June 23, 2010), http://www.brookings.edu/research/papers/2010/06/23-kagan-rogers (interpreting a memorandum prepared by then White House Counsel Kagan to suggest "that, in an appropriate case, Kagan would favor revisiting and revising the Smith decision”).

${ }_{34}$ We cite much of this commentary in Part IV, infra. 
it, however, have either gone undernoticed, or have been framed in ways that obscure rather than inform full comprehension of what it signifies. This Section focuses primarily on those parts of the opinion, with an eye to teasing out its distinctive moves and contributions.

The role of history. The analytic portion of the opinion begins with a brief march through English and American colonial history, focused on controversies over the power of government to appoint clergy. ${ }^{35}$ One might expect that a survey of historically relevant practices, forming the "background [against which] the First Amendment was adopted"36 would be a commonplace in religion clause opinions, but it most certainly is not.

The most famous account of that backdrop occurred in 1947 in Everson, ${ }^{37}$ where every Justice-despite a 5-4 split on the merits-signed on to a narrative that places the history of disestablishment in Virginia, including the crucial role in that history of Madison's Memorial and Remonstrance Against Religious Assessments, at the center of the First Amendment's Religion Clauses. ${ }^{38}$ Justice Black, the author of Everson, later repeated a version of that history in Engel $v$. Vitale, ${ }^{39}$ the Court's first and nearly unanimous school-prayer decision. The historical account in Engel, unsurprisingly, emphasized the prominence of state-sponsored and mandated prayer that was a hallmark of the British establishment at the time of the framing of our First Amendment. ${ }^{40}$ The most focused response to the Everson-Engel account in the Court's subsequent decisions emerged in a powerful dissent in Wallace $v$. Jaffree, ${ }^{41}$ in which Justice Rehnquist argued against the so-called "separationist" model and in favor of a "no sect preference" model of nonestablishment. The latter moves away from the Virginia experience, and the background of Anglicanism in Great Britain and colonial America, and emphasizes the variety of institutional arrangements among the states in church-state relations at the time of the framing.

The normative significance of the gap between these historical accounts is considerable, and the two models accordingly lead to very different outcomes in cases about government funding of religious entities, ${ }^{42}$ government-sponsored worship, ${ }^{43}$ and government display of

${ }^{35}$ Hosanna-Tabor Evangelical Lutheran Church \& Sch. v. EEOC, 565 U.S. 171, 182-85 (2012).

${ }^{36}$ Id. at 183 .

37 Everson v. Bd. of Educ., 330 U.S. 1 (1947).

${ }_{38}$ Compare id. at 8-13 with id. at 33-43 (Rutledge, J., dissenting).

39370 U.S. 421 (1962).

${ }^{40} I d$. at $425-36$.

41472 U.S. 38, 91-113 (1985) (Rehnquist, J., dissenting).

42 See, e.g., Mitchell v. Helms, 530 U.S. 793 (2000).

${ }^{43}$ See, e.g., Lee v. Weisman, 505 U.S. 577 (1992). 
religious symbols. ${ }^{44}$ Issues arising in all of those contexts have been very controversial and divisive within the Court for the past 40 years. Because there was no longer a consensus narrative, the Court had for decades gone relatively quiet on the relevance of American church-state history in the period leading up to the drafting of the First Amendment.

Suddenly, in Hosanna-Tabor, the Justices completely agreed upon a history, because there indeed was a singular account relevant to the particular questions raised by the ministerial exception. The decision does not offer, however, a general history of church-state relations. Instead, it has a precise focus on a specific type of conflict. For separationists, accommodationists, or members of any other relevant school of thought, the historical arguments all pointed in exactly the same direction. Government appointment of clergy was a hallmark of an oppressive state establishment; freedom of religious communities to choose their own leaders is a sine qua non of the free exercise of religion. ${ }^{45}$

The most relevant Religion Clause precedents. With this historical starting place fixed, the Hosanna-Tabor opinion quite logically moved to the appropriate set of precedents. Notably, these did not include decisions about free exercise exemptions, such as Wisconsin v. Yoder, ${ }^{46}$ or decisions about government sponsorship of religion through funds, symbols, or worship. Rather, the Court found most relevant those decisions about the role of the state in disputes about church property, governance, and personnel. Ranging from the 1871 common law ruling in Watson v. Jones ${ }^{47}$ to the First Amendment-based decisions in Kedroff ${ }^{8}$ and Milivojevich, ${ }^{49}$ the central thread of this body of law is steady and unbroken-on matters of religious doctrine, church governance, and control of leadership, the state is forbidden from substituting its judgment for that of duly constituted religious authority. The state must respect the decisions of religious authorities on ecclesiastical questions. ${ }^{50}$ As Hosanna-Tabor goes on to say,

${ }^{4}$ See, e.g., McCreary Cty. v. ACLU of Ky., 545 U.S. 844 (2005); Van Orden v. Perry, 545 U.S. 677 (2005).

${ }^{45}$ For additional details of the relevant history, see Michael McConnell, Reflections on Hosanna-Tabor, 35 Harv. J.L. \& Pub. Pol'y 821, 827-32 (2012). Five states, at the time of their state disestablishments, adopted constitutional provisions that "religious societies have the exclusive right to choose their own ministers." Id. at $829 \&$ n.47. As McConnell argues, this freedom is "part and parcel of disestablishment." Id.; see also Brief Amici Curiae of Professor Eugene Volokh et al. in Support of Petitioner at 10-18, Hosanna-Tabor Evangelical Lutheran Church \& Sch. v. EEOC, 565 U.S. 171 (2012) (No.10-533), 2011 WL 2470847.

${ }^{46} 406$ U.S. 205, 235 (1972).

4780 U.S. (13 Wall.) 679, 733 (1871).

${ }^{48}$ Kedroff v. St. Nicholas Cathedral of the Russian Orthodox Church, 344 U.S. 94, 116 (1952).

${ }^{49}$ Serbian E. Orthodox Diocese v. Milivojevich, 426 U.S. 696, 721 (1976).

${ }^{50}$ When decisions on legally disputed matters of property or personnel can be made without considering ecclesiastical questions, the Constitution is no bar to courts 
the criteria for eligibility to ministry, and the fitness of any particular person for ministry, are precisely such questions. ${ }^{51}$

The roles of the respective Religion Clauses. In this series of earlier decisions involving internal church disputes over property or personnel, a question often arose concerning which Religion Clause was doing the work. As Chief Justice Roberts noted in passing in Hosanna-Tabor, Kedroff makes a reference to the "free exercise of religion.,"52 Viewed more broadly, however, the opinions show that the Court has frequently been content to rely on the "Religion Clauses" or "the First Amendment" more generally. ${ }^{53}$ This unspecified treatment of the distinctive roles of the Free Exercise Clause and the Establishment Clause in the judicial approach to these controversies had for years left commentators reaching for theories that would explain the Court's frequent deference to the decisions of religious authorities. ${ }^{54}$

In Hosanna-Tabor, the Court's longstanding reticence to assign a function to each Religion Clause vanished:

By forbidding the "establishment of religion" and guaranteeing the "free exercise thereof," the Religion Clauses ensured that the new Federal Government-unlike the English Crown-would have no role in filling ecclesiastical offices. The Establishment Clause prevents the Government from appointing ministers, and the Free Exercise Clause prevents it from interfering with the freedom of religious groups to select their own. ${ }^{55}$

As this Article proceeds, we will have considerably more to say about the respective functions, and interactive operations, of the Free Exercise Clause and the Establishment Clause in the foundations of the ministerial exception. But the opinion itself gives two powerful hints of the roles being played by each.

or other state agents making them. Jones v. Wolf, 443 U.S. 595, 604-05 (1979) (holding that courts may apply state law principles to resolve property disputes between church factions, so long as applying these principles does not require decision of ecclesiastical matters); Bouldin v. Alexander, 82 U.S. (15 Wall.) 131, 140 (1872) (holding that courts may apply secular principles of corporate law to decide who within a church has authority to appoint trustees).

${ }^{51}$ Hosanna-Tabor Evangelical Lutheran Church \& Sch. v. EEOC, 565 U.S. 171, 188-90 (2012).

${ }^{52}$ Id. at 186 (citing Kedroff, 344 U.S. at 116).

${ }^{53}$ Milivojevich, 426 U.S. at 710; Presbyterian Church v. Mary Elizabeth Blue Hull Mem'l Presbyterian Church, 393 U.S. 440, 449 (1969).

${ }^{54}$ See, e.g., Kent Greenawalt, Hands Off! Civil Court Involvement in Conflicts over Religious Property, 98 Colum. L. Rev. 1843 (1998).

${ }_{55}$ Hosanna-Tabor, 565 U.S. at 184. Earlier in the opinion, the Chief Justice wrote that despite possible tension between the Religion Clauses in other contexts, there is no such tension here. "Both Religion Clauses bar the government from interfering with the decision of a religious group to fire one of its ministers." Id. at 181. 
First, although free exercise considerations shape the ministerial exception, the Court does not decide the case by balancing interests, in the model represented by Wisconsin $v$. Yoder, ${ }^{56}$ and eventually repudiated by Employment Division v. Smith. ${ }^{57}$ The Court's distinction between the most important constitutional features of Hosanna-Tabor and Smith, both of which involve religious exemptions, is impossible to credit. "[A] church's selection of its ministers," the Court wrote, "is unlike an individual's ingestion of peyote. Smith involved government regulation of only outward physical acts. The present case, in contrast, concerns government interference with an internal church decision that affects the faith and mission of the church itself., ${ }^{58}$

As many others have noted, however, it is utterly unpersuasive to assert that the peyote use involved in Smith is an outward act, while the treatment of Ms. Perich in Hosanna-Tabor is an "internal church decision," thereby distinguishing the cases. Both decisions involve acts that reflect internal church activities, and both have actual or potential external effects.

We elaborate in Part IV about Hosanna-Tabor's unsatisfying treatment of Smith, and the inferences drawn by other commentators from the internal tensions set up by this treatment. Here, we note only that the opinion's discussion of Smith is, in the context of the ministerial exception, a disavowal of the methodology of interest balancing associated with preSmith free exercise adjudication. ${ }^{59}$ The Court's final full paragraph in Hosanna-Tabor eliminates any possibility of doubt about the rejection of that methodology in decisions about the scope of the ministerial exception:

The interest of society in the enforcement of employment discrimination statutes is undoubtedly important. But so too is the interest of religious groups in choosing who will preach their beliefs, teach their faith, and carry out their mission. When a minister who has been fired sues her church alleging that her termination was discriminatory, the First Amendment has struck the balance for us. The church must be free to choose those who will guide it on its way. ${ }^{60}$

The idea that "the First Amendment has struck the balance for us," as distinguished from case-by-case judicial balancing of competing interests, is not only a rejection of now-abandoned Free Exercise methodology. It also represents an affirmative embrace of long-standing Establish-

${ }^{56} 406$ U.S. 205, 215 (1972).

57494 U.S. 872, 884-85 (1990).

58 Hosanna-Tabor, 565 U.S. at 190.

59 See Yoder, 406 U.S. at 215; Sherbert v. Verner, 374 U.S. 398 (1963). That methodology is now the centerpiece of the Religion Freedom Restoration Act, 42 U.S.C. $\$ \S 2000$ bb to bb-4 (2012).

${ }^{60}$ Hosanna-Tabor, 565 U.S. at 196. 
ment Clause methodology, in which decisions are definitional and dispositive. Once a practice, such as school sponsored prayer $^{61}$ or direct government funding of the construction of space for worship ${ }^{62}$ is judicially determined to be an establishment of religion, the case is over. Competing government interests play no part. In its distinction of Smith and its rejection of interest balancing, Hosanna-Tabor sent a signal of profound importance about the respective role of each of the Religion Clauses and the methodology of Religion Clause adjudication appropriate to this case.

We are fully mindful that the Hosanna-Tabor opinion gives equal weight to the Establishment Clause and the Free Exercise Clause. In addition to mentioning both Clauses, the Court remarks that "the text of the First Amendment ... gives special solicitude to the rights of religious organizations." ${ }^{63}$ That language-though oddly connected to the text, which says nothing about religious organizations-seems firmly anchored in a rights-based conception of the free exercise of religion. As we will develop further in Part III, however, the Clauses converge on the proposition, both structural and rights-reinforcing, that the state may not decide "purely ecclesiastical questions." In embracing both Religion Clauses, rejecting interest balancing, and distinguishing Smith, what HosannaTabor disclaims is a sweeping theory of church autonomy that inevitably

${ }^{61}$ Lee v. Weisman, 505 U.S. 577, 580 (1992); Abington Sch. Dist. v. Schemmp, 374 U.S. 203, 205 (1963); Engel v. Vitale, 370 U.S. 421, 422 (1962).

${ }^{62}$ Comm. for Pub. Educ. \& Religious Liberty v. Nyquist, 413 U.S. 756, 798 (1973) (holding that the state may not finance cost of chapel reconstruction in religious school); Tilton v. Richardson, 403 U.S. 672, 689 (1971) (finding that United States may not finance cost of an academic building that may someday be available for worship or religious instruction).

${ }^{63}$ Hosanna-Tabor, 565 U.S. at 189. The context for this remark is the repudiation of the government's argument that religious organizations have no greater right than secular entities to be free from government interference in selecting leaders. In response to that argument, the Chief Justice wrote: "That result is hard to square with the text of the First Amendment itself, which gives special solicitude to the rights of religious organizations. We cannot accept the remarkable view that the Religion Clauses have nothing to say about a religious organization's freedom to select its own ministers." Id. Although "the text of the First Amendment" makes no mention whatsoever of "religious organizations," the Religion Clauses do express special constitutional concern about religion (non-establishment), and special constitutional respect for religion's free exercise. The opinion's very next sentence does no more than reinforce the rest of the opinion by suggesting that "the Religion Clauses have [something] to say about a religious organization's freedom to select its own ministers." Id. Indeed, they do, for the reasons we advance in this paper, rather than because religious organizations are entitled to "special solicitude" even in the absence of ecclesiastical questions. See Part IV.A., infra. 
would require the weighing of burdens on religious exercise against opposing state interests. ${ }^{64}$

The judicial role in administering the ministerial exception. The methodology deployed in Hosanna-Tabor, whatever its particular nexus with either Religion Clause, pervades and illuminates all of the other crucial sections of the opinion. The ministerial exception is about definition and scope, rather than any general weighing of church interests against competing concerns of government.

With respect to the questions of which employees and what causes of action are covered by the exception, the Hosanna-Tabor opinion makes a number of distinctive and revealing moves. All of them reinforce the notion that the ministerial exception is driven-precisely as the citations to Watson, Kedroff, and Milivojevich suggest—by the long-standing doctrine of judicial abstention from deciding purely ecclesiastical questions.

With respect to which employees fall under the exception, the Court engages in a careful and independent appraisal of Ms. Perich's employment role. Focusing in considerable detail on her title, training, selfunderstanding as a minister, and specific duties, the Court concluded that she "performed an important role in transmitting the Lutheran faith to the next generation."

This question of role is functional, not ecclesiastical. Were the question of ministerial status ecclesiastical, employers would be free to answer it unilaterally, in a wholly self-interested way. Nothing could stop a house of worship from asserting that all its employees, from priest to custodian, transmit the faith by serving as role models. The emphasis in HosannaTabor on training, title, and, most importantly, on particularized tasksteaching, leading others in worship, and otherwise communicating the faith through words-means that courts must decide, based on evidence, whether the ministerial exception applies to a specific position. ${ }^{66}$

Retention of judicial control over the factual predicates of the ministerial exception, case by case, fully illuminates the opinion's already famous footnote four, ${ }^{67}$ in which the Court asserts that the ministerial ex-

${ }^{64}$ We thus disagree with Professor Gedicks's assessment that Hosanna-Tabor is incoherent in its simultaneous embrace of the structural norms of the Establishment Clause and the rights-based norms associated with the Free Exercise Clause. See Gedicks, Narrative Pluralism and Doctrinal Incoherence, supra note 22, at 421-33. Hosanna-Tabor rests on both Clauses, but reaffirms Smith in rejecting the interestbalancing methodology once associated with the Free Exercise Clause and now embodied in the Religious Freedom Restoration Act.

${ }^{65}$ Hosanna-Tabor, 565 U.S. at 192.

${ }^{66} I d$. at 191-94. Only Justice Thomas would defer to the characterization of the religious community with respect to who counts as a minister. Id. at 710-11 (Thomas, J., concurring).

${ }^{67}$ Id. at 195 n.4. See generally Michael A. Helfand, Religion's Footnote Four: Church Autonomy as Arbitration, 97 MinN. L. REv. 1891 (2013). 
ception "operates as an affirmative defense to an otherwise cognizable claim, not a jurisdictional bar., ${ }^{, 68}$ If the exception arose simply from the status of the defendant as a religious entity, coupled with a unilateral assertion that the plaintiff is a ministerial employee, those features in conjunction would deprive the court of "power to hear the case," Court puts it.

Viewed as an affirmative defense, however, the exception requires more than a defendant's status as a religious entity and its assertions of the employee's role. Whether the employee is actually engaged in "minister[ing] to the faithful-a matter "strictly ecclesiastical" "70 - may involve disputed questions of fact. The plaintiff-employee is entitled to contest the characterization of her role as ministerial by offering proof of facts that would show that she does not engage in ministry. Accordingly, contested assertions that a case is governed by the ministerial exception must be resolved through a separate motion for summary judgment, or a separate evidentiary hearing with the opportunity for both sides to present evidence of the employee's role. ${ }^{71}$

Moreover, if the court determines that the plaintiff and the claim she presents are covered by the ministerial exception, the reasons for the defendant's actions become irrelevant. In responding to the government's argument that Hosanna-Tabor's asserted reason for firing Perich-"that she violated the Synod's commitment to internal dispute resolution"was pretextual, ${ }^{72}$ the Court responds bluntly:

That suggestion misses the point of the ministerial exception. The purpose of the exception is not to safeguard a church's decision to fire a minister only when it is made for a religious reason. The exception instead ensures that the authority to select and control who will minister to the faithful-a matter 'strictly ecclesiastical' . . - -is the church's alone. ${ }^{73}$

If the court determines that the employee is not a minister for purposes of the exception, the case may proceed to the merits. ${ }^{74}$ Moreover, even if the case involves a ministerial employee, some claims may still not be barred. The Court explicitly recognizes this possibility in the HosannaTabor opinion:

${ }^{68}$ Hosanna-Tabor, 565 U.S. at 195 n.4.

${ }^{69}$ Id. (quoting Morrison v. Nat'l Austl. Bank, 561 U.S. 247, 254 (2010)).

${ }^{70}$ Id. at 195 (quoting Kedroff v. St. Nicholas Cathedral of the Russian Orthodox Church, 344 U.S. 94, 119 (1952)).

${ }^{71}$ See Part III, infra, for further discussion of the connection between HosannaTabor's footnote four and an Establishment Clause-based theory of adjudicative disability.

${ }^{72}$ Hosanna-Tabor, 565 U.S. at 194.

${ }^{73}$ Id. at 194-95 (citing Kedroff, 344 U.S. at 119).

${ }^{74}$ See pp. 1285-86, infra, for discussion of why interlocutory appellate review should be allowed for a denial of the ministerial exception. 
The case before us is an employment discrimination suit brought on behalf of a minister, challenging her church's decision to fire her. Today we hold only that the ministerial exception bars such a suit. We express no view on whether the exception bars other types of suits, including actions by employees alleging breach of contract or tortious conduct by their religious employers. ${ }^{75}$

In Part III below, we analyze the kinds of claims that courts have correctly held are not covered by the ministerial exception. For now, it is enough to observe that Hosanna-Tabor, by its own terms, does not represent any sweeping proclamation of the immunity of religious entities from liability to their employees, ministerial or otherwise, or to members of their religious community. Its rationale is limited to questions concerning the fitness of a particular person for ministry on behalf of her employer. These are ecclesiastical questions, and the Constitution puts them off limits to the state, including its courts. That, and nothing more or less, is the content of the unanimous ruling in Hosanna-Tabor Evangelical Lutheran School E Church v. EEOC.

\section{A DEFENSE AND ELABORATION OF HOSANNA-TABOR}

Hosanna-Tabor bars government agencies from adjudicating specific types of disputes between religious institutions and those who teach, preach, or otherwise guide the faithful. As the opinion reveals, that limitation on government power draws primarily on Establishment Clause methodology of carving out areas of forbidden government action, like officially sponsored prayer in public school, rather than a free exercise approach of weighing burdens on religion against competing state interests.

The strong Establishment Clause foundations of Hosanna-Tabor are substantive, as well as methodological. Accordingly, Hosanna-Tabor lines up quite closely with the central ideas in our prior work. In Secular Government, Religious People, ${ }^{76}$ we articulate a theory of the Religion Clauses that emphasizes the long-standing constitutional commitment to sharply delimit the state's involvement with religion and religious institutions. The jurisdiction of government in the United States, at all levels, may not encompass efforts to control or shape the people's religious character. However controversial this theory may be with respect to government's acknowledgment of theological sentiments, ${ }^{77}$ celebration of religious hol-

${ }^{75}$ Hosanna-Tabor, 565 U.S. at 196.

${ }^{76}$ Ira C. Lupu \& Robert W. Tuttle, Secular Government, Religious People 30-33 (2014); see also Ira C. Lupu \& Robert W. Tuttle, The Distinctive Place of Religious Entities in Our Constitutional Order, 47 VilL. L. REv. 37, 38-39 (2002).

77 The Court has been deeply divided in such cases. See, e.g., Town of Greece v. Galloway, 134 S. Ct. 1811 (2014); Van Orden v. Perry, 545 U.S. 677 (2005); McCreary 
idays,${ }^{78}$ or financial support of religious institutions, ${ }^{79}$ the unanimity in Hosanna-Tabor shows the rock-solid qualities of the jurisdictional view when the context is selection of clergy and religious teachers.

We make no claims to novelty in our constitutional narrative of the relationship between the state and the people's religious character. The basic features of that narrative predate the First Amendment, and continue in the law right up to the present moment. It is beyond dispute that the Establishment Clause takes much of its meaning from the founding generation's experience with established churches, in both Great Britain and the colonies. ${ }^{80}$ Government officials in Great Britain regularly exercised the power to decide ecclesiastical questions. They did so by defining the beliefs to which all clergy must conform, directly controlling the appointment of the most senior clerics, and expelling from ministry those who failed to carry out government-prescribed modes of worship. ${ }^{81}$ Some British colonies in North America maintained similar control over clergy. ${ }^{82}$

In the American colonies, two movements-one religious and the other political-ultimately destroyed that British tradition of government power over the instruments of faith. In religious terms, beginning in the mid-18th century, evangelists of the First Great Awakening denied the authority of state-selected ministers, and asserted that the blessing of the Holy Spirit provides the sole basis of any minister's calling. ${ }^{83}$ In political terms, the American Revolution provided a sharp break from Anglican tradition of state control over clergy. ${ }^{84}$ By the late 18 th century, state officials played virtually no role in the selection of ministers, even in those jurisdictions that maintained state financial support for churches. $^{85}$ Whatever else belonged to the original sphere of American disestablishment, the exclusion of state control over employment of clergy soon became an unchallenged and universal element.

Cty. v. ACLU of Ky., 545 U.S. 844 (2005). For discussion, see Lupu \& TutTle, supra note 76 , at $141-74$.

${ }^{78}$ See Cty. of Allegheny v. ACLU, 492 U.S. 573, 615 (1989); Lynch v. Donnelly, 465 U.S. 668, 676 (1984).

${ }^{79}$ See, e.g., Zelman v. Simmons-Harris, 536 U.S. 639, 652 (2002); Mitchell v. Helms, 530 U.S. 791 (2000). For discussion of the funding decisions, see LupU \& TutTle, supra note 76 , at 74-112.

${ }^{80}$ LUPU \& TUTTLE, supra note 76 , at 8-9.

${ }^{81} I d$.

${ }^{82} I d$. at 9 .

${ }^{83}$ James H. Hutson, Church and State in America: The First Two Centuries 78-84 (2008); Mark Noll, The Rise of Evangelicalism: The Age of Edwards, WHiteFIELD, AND THE WESLEys 129-30, 147-48, 179-83 (2003).

${ }^{84}$ See generally Patricia U. Bonomi, Under the Cope of Heaven: Religion, Society, And Politics in Colonial America 187-216 (updated ed. 2003).

${ }^{85}$ McConnell, supra note 45, at 828. 
In disputes that involve the choice of clergy and other religious questions, these religious and political developments have generated a distinctive American legal tradition. Beginning with its very first engagement with this type of problem, the Supreme Court has consistently held that government may not resolve "strictly and purely ecclesiastical" questions. ${ }^{86}$ This idea of limited judicial competence is an attribute of disestablishment, although, as Hosanna-Tabor appropriately recognizes, this constraint simultaneously promotes the free exercise of religion. By removing the power of the state to resolve ecclesiastical questions, the Constitution maximizes space for religious communities to decide for themselves crucial issues of governance, doctrine, and the identity of those who will articulate that doctrine. ${ }^{87}$

To appreciate fully how the ministerial exception implicates ecclesiastical questions, one must unpack the components of the exception and understand their interrelatedness. First and foremost, the exception forecloses judicial inquiry into the criteria that religious communities use to measure eligibility for positions involving communication of the faith. For some traditional communities, these criteria include sex, but they might also include marital status, sexual orientation, age, education, experience, ancestry, or even race. Contrary to the expectations of those untutored in this field of law, very few ministerial exception cases in the courts involve direct challenges to overt and otherwise unlawful criteria for employment.

The typical case in which the ministerial exception is claimed involves religious communities that raise the exception as a defense when a member of their clergy accuses them of discrimination that is both generally unlawful and a violation of the community's own publicly pronounced norms. In such a case, the ecclesiastical question is not one of general eligibility for ministry, but rather of the fitness of a particular person for ministry.

${ }^{86}$ Watson v. Jones, 80 U.S. (13 Wall.) 679, 733 (1871).

${ }^{87}$ Even apart from disputes over the control of property or the appointment of ministers, the Establishment Clause facilitates religious freedom by removing the state from distinctively religious activities. It leaves the control and performance of those activities to private individuals and communities. For example, in Engel v. Vitale, 370 U.S. 421, 435 (1962), the Court held that the Establishment Clause bars state officials from authoring prayers for use in public schools. Responding to those who asserted that a ban on school-sponsored prayer was hostile to religion, Justice Black, writing for the Court, said: "It is neither sacrilegious nor antireligious to say that each separate government in this country should stay out of the business of writing or sanctioning official prayers and leave that purely religious function to the people themselves and to those the people choose to look to for religious guidance." Id. at 435. Engel thus promotes religious freedom, but it does not do so by creating exemptions or opt-out rights for objectors, religious or otherwise. Instead, it promotes free exercise values by delineating the respective domains of government and religion. 
Indeed, this is an apt description of the case of Cheryl Perich, whom Hosanna-Tabor dismissed for complaining to a government agency of what she viewed as discrimination based on disability. ${ }^{88}$ Whether or not this reason for dismissal qualifies as religious, ${ }^{89}$ Ms. Perich's formal complaint to the EEOC disqualified her from ministry at Hosanna-Tabor, and that particularized and personal disqualification represented an ecclesiastical determination.

In many ministerial exception cases, the employee asserts that the adverse job action was made on a legally forbidden ground. In response, the employer generally offers a different and valid reason for the action. In cases of this character, some scholars (grouped below as the "Dissenters") have argued strenuously that courts should adjudicate the true reason for the adverse job action. ${ }^{90}$ These critics believe that if courts find that the true reason is legally discriminatory, and that the asserted reason is nothing more than a pretext for that discrimination, courts should not apply the ministerial exemption.

Hosanna-Tabor rightly rejects that position. Once the court finds that the plaintiff occupies a ministerial position, and that the substance of the claim is covered by the exception, the case must end. In such cases, recognizing the ministerial exception serves the prophylactic function of fully recognizing the adjudicative disability of courts with respect to fitness for ministry, and thereby protecting religious communities from both inappropriate intrusion and the risk of erroneous determinations. Suppose such pretext inquiries were allowed. Judges and juries would hear evidence with respect to the plaintiff's performance of her clerical responsibilities, as well as evidence that performance criteria were being applied in a discriminatory way. As we wrote in a piece published several years prior to Hosanna-Tabor, ${ }^{91}$ in light of a detailed analysis of the pretext problem:

Courts cannot decide whether a congregation has engaged in discriminatory conduct toward a ministerial employee without first determining a set of qualifications for holding the role, or a standard of performance within the role, and then measuring the employee's

${ }^{88}$ Hosanna-Tabor Evangelical Lutheran Church \& Sch. v. EEOC, 565 U.S. 171, 179 (2012).

${ }^{89}$ Hosanna-Tabor asserted that Perich violated religious norms about appropriate mechanisms for dispute resolution, but the Court's opinion explicitly says the reason for dismissal need not be religious. $I d$. at 194 ("The purpose of the exception is not to safeguard a church's decision to fire a minister only when it is made for a religious reason.").

${ }^{90}$ See, e.g., Corbin, supra note 24, at 2015-22; see also Gedicks, Narrative Pluralism and Doctrinal Incoherence, supra note 22, at 426-27.

${ }^{91}$ Lupu \& Tuttle, supra note 10. 
conduct ... against these standards. Such acts of measurement are beyond the state's adjudicative competence. ${ }^{92}$

If civil courts were free to invalidate decisions made by religious authorities under these circumstances, the courts would be substituting the judgment of the state for that of the religious community with respect to the role and content of ministry. Even if that constitutional vice were avoidable, courts could not warrant that pretext adjudication would proceed with perfect accuracy. The inevitability of mistake means that, in an unknowable fraction of cases, the state would be imposing unjustifiable pressure on religious entities to refrain from an adverse job action. That pressure is less troublesome than a wholly external appointment by the government of a minister, but it necessarily coerces a religious community to retain a minister it no longer wants. ${ }^{93}$

Within its boundaries concerning which employees are covered and the kinds of claims that are encompassed, the ministerial exception is fortress-like. ${ }^{94}$ Just like other nonestablishment limitations, it cannot be defeated by competing considerations of legal policy. That the exception is grounded, at least in part, in the Establishment Clause means that cases that fall under the exception involve the government's constitutional disability to adjudicate, producing a corresponding defendant's immunity from adjudication. ${ }^{95}$ In the operation of the ministerial exception, the impermissibility of pretext adjudication thus reveals once again the perfect convergence of Establishment Clause and Free Exercise Clause considerations.

Because the exception is impenetrable within its boundaries, it is crucial that courts, not religious institutions, retain full authority to draw

${ }^{92} I d$. at 144 (analogizing the issues to those presented by claims for clergy malpractice).

${ }^{93}$ For this reason, even advocates of pretext adjudication concede that the remedy of ordering a clergy member reinstated to her position is, at least in some circumstances, constitutionally inappropriate. See Corbin, supra note 24, at 2015-22. That concession is a recognition of the constitutional distinctiveness and sensitivity of this employer-employee relationship. The risk of damage awards is a weaker form of compulsion, but nevertheless exerts pressure to retain an unwanted minister, and may well prevent the congregation from hiring a replacement minister. Thus, even in the context of pretext claims, a nonestablishment concern produces free exercise payoffs.

${ }_{94}$ Marc DeGirolami, Free Exercise by Moonlight, 53 SAn Diego L. Rev. 105, 127-29 (2016) (making a similar point about the strength of the exception within its boundaries, although he does not connect the point to the exception's Establishment Clause provenance).

${ }_{95}$ As we explain in Lupu \& Tuttle, supra note 10, at 122 n.20, these terms build on a Hohfeldian conception of legal rights. See also Frederick M. Gedicks, The Religious Question Doctrine: Free-Exercise Right or Anti-Establishment Immunity? (Robert Schuman Ctr. for Advanced Studies, Working Paper No. 2016/10, 2016), http:// papers.ssrn.com/sol3/papers.cfm?abstract_id=2746593. 
those boundaries. Hosanna-Tabor embraces that allocation of power. ${ }^{96}$ By locating in civil courts the authority to determine the applicability of the exception, the doctrine ensures that defendants do not get to be judges in their own cause.

Once the ministerial exception is understood in this way, it follows that the procedure used in litigating whether an employee plaintiff is covered by the exception has constitutional dimensions. The affirmative defense of "ministerial exception" should not simply be thrown into the mix of claims and defenses present in a particular case. Instead, courts should employ a carefully constructed procedure, designed to determine 1) whether the employee's position is ministerial, and 2) whether the claim implicates her ministerial character, before proceeding to general discovery. If these determinations are folded into broad-ranging discovery procedures, much of the significance of the immunity will be lost. Discovery would raise questions about the plaintiff's fitness for ministry, even though the trier of fact is constitutionally disabled from adjudicating that question. If the employee is a minister for purposes of the exception, any part of the case that raises the question of fitness for that ministry must end. ${ }^{97}$

For the same reasons, interlocutory appellate review should be allowed for a denial of the ministerial exception by a court of first impression; otherwise, the case's full merits may be unconstitutionally adjudicated, and the defendant's procedural immunity from that adjudication breached, by an erroneous decision that the ministerial exception does not apply. ${ }^{98}$ Furthermore, the Establishment Clause provenance of the ministerial exception means that courts remain obliged to inquire, sua sponte, into the applicability of the ministerial exception, even if the defendant does not raise the question. ${ }^{99}$ As the Sixth Circuit recently held

${ }^{96}$ Hosanna-Tabor Evangelical Lutheran Church \& Sch. v. EEOC, 565 U.S. 171, 190-95 (2012). Courts may not decide ecclesiastical questions, but they must decide whether a particular position involves transmission of the faith. That is a functional question, not a religious one.

${ }^{97}$ In this respect, we disagree with the result in Temple Emanuel of Newton $v$. Mass. Comm'n Against Discrimination, 975 N.E.2d 433, 441 (Mass. 2012), which held that the Commission could proceed to the merits of a discrimination claim without awaiting final judicial resolution of a ministerial exception defense. Administrative convenience does not trump constitutional disability.

${ }_{98}$ The context is thus somewhat analogous to cases involving claims of the immunity of government officers from individual damage awards for violation of federal law; in such cases, claims of qualified immunity are raised and resolved in advance of the merits, and denials of immunity are subject to interlocutory review. See Mitchell v. Forsyth, 472 U.S. 511, 524-30 (1985).

${ }^{99}$ EEOC v. Catholic Univ. of Am., 83 F.3d 455, 461-63 (D.C. Cir. 1996) (describing ministerial exception as a hybrid of Establishment Clause and Free Exercise Clause considerations); id. at 459 (approving action of the district court judge in raising sua sponte the question of whether a position as professor of canon 
in the precise context of the ministerial exception, the parties do not have power to waive the constitutional disabilities of the courts. ${ }^{100}$

Even with respect to employees with ministerial responsibilities, not all claims against their institutional employers should fall within the adjudicative disability created by the ministerial exception. The disability is issue-based, not party-based, so it remains open in each case to ask whether some or all of the relevant issues are constitutionally foreclosed. The Hosanna-Tabor opinion explicitly recognized the necessity of such an inquiry when it flagged the possibility that the ministerial exception might not bar various tort and contract claims by clergy against their employers. ${ }^{101}$ "There will be time enough," the Court wrote, "to address the applicability of the exception to other circumstances if and when they arise." ${ }^{102}$

Such circumstances have arisen in the courts prior to Hosanna-Tabor, and they continue to arise in that decision's wake. As we analyzed this set of questions in elaborate detail in $2009,{ }^{103}$ the pattern of decisions in the lower courts matched tightly with our appraisal that the exception is entirely issue-based, rather than driven solely by the character of the parties. For a prominent example, courts have systematically rejected claims of clergy malpractice on the grounds that the standard of care for counseling by clergy would inevitably encompass ecclesiastical questions about the minister-congregant relationship. ${ }^{104}$ In contrast, many courts have permitted claims by victims of sexual abuse against religious organizations for negligent supervision of offending clergy. ${ }^{105}$ In such cases, the relevant legal questions pertain to decisions about exposing potential vic-

law is covered by the ministerial exception); see also LuPU \& TutTLE, supra note 76, at 38 (" $[\mathrm{A}] \mathrm{s}$ is true of other questions of constitutional structure, judges must be mindful that constitutional allocations of power may not be altered by agreement of the parties involved-neither the state, nor any religious believers, may consent to a swap of constitutionally separated functions.").

${ }^{100}$ Conlon v. Intervarsity Christian Fellowship, 777 F.3d 829, 836 (6th Cir. 2015) ("The ministerial exception is a structural limitation imposed on government by the Religion Clauses, a limitation that can never be waived."). For a comprehensive account of the relationship between the ministerial exception and the prohibition on judicial resolution of ecclesiastical questions, see Tomic v. Catholic Diocese of Peoria, 442 F.3d 1036, 1037-40 (7th Cir. 2006). Judge Posner's opinion in Tomic rests on Article III, id. at 1037-38, as well as the First Amendment's Religion Clauses, id. at 1039, 1042.

${ }^{101}$ Hosanna-Tabor, 565 U.S. at 196 ("We express no view on whether the exception bars other types of suits, including actions by employees alleging breach of contract or tortious conduct by their religious employers.").

$102 I d$.

103 See Lupu \& Tuttle, supra note 10.

$104 \quad I d$. at 142-43; see infra note 136.

${ }^{105}$ Ira C. Lupu \& Robert W. Tuttle, Sexual Misconduct and Ecclesiastical Immunity, 2004 BYU L. Rev. 1789, 1851-56, 1851 n.243 (2004) (citing and discussing decisions that allow claims of negligent supervision to go forward). 
tims to known or foreseeable risks of physical and dignitary harm, not to decisions about whether a particular person is fit for ministry. Whether to revoke a person's status as a minister is exclusively the church's business; keeping predators away from children and other potential victims is appropriately a matter for the State's concern, as well as that of responsible religious communities. ${ }^{106}$

The clergy malpractice cases and the sexual abuse cases are suits by third parties, not suits by clergy themselves. But the relevant principles of disability and immunity apply with equal force in suits brought by clergy against present or former employers. The best example of when ministerial exception principles do not preclude adjudication involves claims of sexual harassment by clergy against their supervisors and employers. ${ }^{107}$ Adjudication of the cause of action, despite its grounding in statutory prohibition of sex discrimination, does not necessarily require any decision about the plaintiff's fitness for ministry. ${ }^{108}$ Courts may need to separate claims of wrongful termination from those of sexual harassment, but the ministerial exception does not bar the harassment claim. ${ }^{109}$ Moreover, just as one would expect from the premises of our theory, courts have been willing to resolve claims by ministers of breach of contract by their employers, ${ }^{10}$ but only to the extent that the questions of breach do not involve evaluation of ministerial performance or other ecclesiastical questions. ${ }^{111}$

Did the Court's decision in Hosanna-Tabor alter this pattern of results and reasoning? Following research methods we have employed in this as well as other contexts, ${ }^{112}$ we have examined every reported decision, state and federal, that cites Hosanna-Tabor between the time of decision in January 2012 and the middle of 2016. The results emphatically support our reading of Hosanna-Tabor.

The most predictable decisions are those in which an employee with indisputably ministerial duties litigates a claim involving a direct determination of fitness for the ministerial post. Whether the cause of action involved claims of discrimination, ${ }^{113}$ or attempts to review dismissals as ei-

${ }^{106} I d$. at 1846 \& nn.224-28 (citing and discussing decisions forbidding claims of negligent ordination).

${ }^{107}$ Lupu \& Tuttle, supra note 10, at 160-63, 160 n.218.

108 Even in sexual harassment cases, the exception bars the remedy of reinstatement. Bollard v. Ca. Province of the Soc'y of Jesus, 196 F.3d 940, 950 (9th Cir. 1999).

109 Lupu \& Tuttle, supra note 10, at 160-63.

${ }^{110}$ Id. at 144-46.

${ }^{111} I d$. at $146 \&$ nn.151-52.

112 See, e.g., Lupu \& Tuttle, supra note 10; Lupu \& Tuttle, supra note 105.

113 Conlon v. Intervarsity Christian Fellowship, 777 F.3d 829, 834 (6th Cir. 2015). 
ther tortiously wrongful ${ }^{114}$ or lacking contractual "cause, ${ }^{115}$ these cases fall squarely in the path of Hosanna-Tabor, and the claims are barred.

As one would expect, a number of cases involve a dispute over application of Hosanna-Tabor's multi-factor test for who qualifies as a ministerial employee. After close, fact-specific analysis, as required by HosannaTabor, of an employee's particular roles and duties, courts have held that the exception covers a church music director; ${ }^{116}$ a principal of a Catholic high school; ${ }^{117}$ a drug counselor in a religious mission; ${ }^{118}$ an officer in a Methodist agency for interfaith dialogue; ${ }^{119}$ a nonordained teacher of Jewish studies in an afterschool educational program at a synagogue; ${ }^{120}$ and a chaplain in a religiously affiliated hospital. ${ }^{121}$ And, after similarly close analysis, courts have excluded from the exception a facilities manager at a synagogue; ${ }^{122}$ a variety of religious school employees, including a language arts teacher, ${ }^{123}$ a technology teacher, ${ }^{124}$ and a food services director; ${ }^{125}$ and, perhaps most strikingly, a professor of religious studies at a seminary, because his teaching duties did not include transmission of the faith. ${ }^{126}$

${ }^{114}$ Ginyard v. Church of God in Christ Ky. First Juris., Inc., 6 F. Supp. 3d 725, 727 (W.D. Ky. 2014); Melhorn v. Balt. Wash. Conf. of United Methodist Church, No. 2065, 2016 WL 1065884, at*1 (Md. Ct. Spec. App. Mar. 16, 2016); Greater Fairview Missionary Baptist Church v. Hollins, 2013-IA-01951-SCT (I5) (Miss. 2015).

${ }^{115}$ Winbery v. La. Coll., 2013-339, pp. 2-3 (La. App. 3 Cir., Nov. 6, 2013), 124 So.3d 1212, 1214; Simons v. Lewis, No. C-92-1, 2014 WL 4916616, at *2-4 (N.J. Super. Ct. App. Div., Oct. 2, 2014); Warnick v. All Saints Episcopal Church, 2011 No. 01539, 2014 WL 11210513, at*1-5 (Pa. Ct. Com. Pl., Apr. 15, 2014); Reese v. Gen. Assembly of Faith Presbyterian Church in Am., 425 S.W.3d 625, 626 (Tex. App. 2014); DeBruin v. St. Patrick Congregation, 2012 WI 94, I5, 343 Wis. 2d 83, 93, 816 N.W.2d 878, 883.

${ }^{116}$ Cannata v. Catholic Diocese of Austin, 700 F.3d. 169, 180 (5th Cir. 2012).

117 Fratello v. Roman Catholic Archdiocese of N.Y., No. 12-CV-7359, 2016 WL 1249609, at*1 (S.D.N.Y., Mar. 29, 2016).

118 Rogers v. Salvation Army, No. 14-12656, 2015 WL 2186007, at*1 (E.D. Mich., May 11, 2015).

${ }^{119}$ Mills v. Standing Gen. Comm'n on Christian Unity, 986 N.Y.S.2d 60 (N.Y. App. Div. 2014).

${ }_{120}$ Temple Emanuel of Newton v. Mass. Comm'n Against Discrimination, 975 N.E.2d 433, 443 (Mass. 2012).

${ }^{121}$ Penn v. N.Y. Methodist Hosp., 158 F. Supp. 3d 177, 178 (S.D.N.Y. 2016).

${ }^{122}$ Davis v. Balt. Hebrew Congregation, 985 F. Supp. 2d 701, 711 (D. Md. 2013).

${ }^{123}$ Herx v. Diocese of Fort Wayne-South Bend Inc., 48 F. Supp. 3d 1168, 1177 (N.D. Ind. 2014).

${ }^{124}$ Dias v. Archdiocese of Cincinnati, No. 1:11-CV-00251, 2012 WL 1068165, at *5 (S.D. Ohio, Mar. 29, 2012)

${ }^{125}$ Barrett v. Fontbonne Acad., No. NOCV2014-751, 2015 WL 9682042, at *11 (Mass. Super. Ct., Dec. 16, 2015).

${ }^{126}$ Kant v. Lexington Theological Seminary, 426 S.W.3d 587, 596 (Ky. 2014). See generally Kevin Murphy, Administering the Ministerial Exception, Post Hosanna-Tabor: Why Contract Claims Should Not Be Barred, 28 Notre Dame. J.L. Ethics \& Pub. Pol'y 
Our view of Hosanna-Tabor is most starkly confirmed by a series of decisions in which the relevant concern is whether the case requires adjudication of strictly ecclesiastical questions. When it does, adjudication does not go forward, whether or not a ministerial employee is involved. And when the case does not involve decision of such a question, adjudication does go forward, even if a ministerial employee is involved. Put differently, in cases that fall under the sweep of Hosanna-Tabor and the long line of decisions it extends, the presence of a ministerial employee is neither necessary nor sufficient to bar adjudication. It is the presence of ecclesiastical questions, including fitness of a particular person for ministry, that produces a constitutional impediment to adjudication. It is hard to imagine positive law evidence more corroborative of our theory than this.

In perfect accord with the constitutional narrative we espouse, several decisions bar adjudication of claims against religious communities entirely because of the ecclesiastical questions involved, whether or not the party raising them has ministerial status. In Erdman v. Chapel Hill Presbyterian Church ${ }^{127}$ for example, the Washington State Supreme Court refused to adjudicate the lawfulness of a dismissal of an employee who complained about potential misuse of funds by a senior pastor. Without deciding whether the plaintiff was a ministerial employee, ${ }^{128}$ the Court concluded that the claim involved ecclesiastical questions of internal church adjudication and governance. And in Weiter v. Kurtz, ${ }^{129}$ a nonministerial employee brought a claim for wrongful discharge after he was dismissed for complaining about the assignment of a priest who had been sexually abusive. The Kentucky Court of Appeals held that in this context, the question of assignment was an unreviewable ecclesiastical question. ${ }^{130}$

Most revealing of all, however, are decisions allowing adjudication of claims by ministerial employees against their religious institutional employers. These include, as Hosanna-Tabor signaled, ${ }^{131}$ matters arising in both contract and tort. A recent, prominent, and well-reasoned example is Kirby $v$. Lexington Theological Seminary, ${ }^{132}$ in which the Kentucky Supreme

383 (2014) (arguing that contract claims between ministerial employees and their employers should be barred only if interpretation of the contract involves ecclesiastical questions).

127286 P.3d 357, 362 (Wash. 2012).

${ }^{128} I d$. (remanding because facts not sufficiently developed to decide "ministerial exception" question).

129 2011-CA-001058-MR, 2012 WL 6213759, at *8 (Ky. Ct. App., Dec. 12, 2012).

${ }^{130} I d$. Note that the assignment would have been reviewable in the context of a suit by the victim of post-assignment sexual abuse, because it would then present the secular question of whether the defendants had created a foreseeable and unreasonable risk of harm to a third party.

${ }^{131}$ Hosanna-Tabor Evangelical Lutheran Church \& Sch. v. EEOC, 565 U.S. 171, 196 (2012)

132426 S.W.3d 597 (Ky. 2014). 
Court held that the ministerial exception barred a claim of race discrimination by a tenured professor of Christian social ethics ${ }^{133}$ but that the exception did not bar the same plaintiff's claims for breach of contract with respect to the conditions under which tenure could be revoked. The court explicitly disavowed the authority to adjudicate ecclesiastical questions that might arise under the contract, while asserting the authority to determine whether the Seminary's financial exigency justified dismissal. The latter question was entirely secular, and therefore open for decision, even though the plaintiff was a ministerial employee. ${ }^{134}$

Similarly, in Bigelow v. Sassafras Grove Baptist Church ${ }^{135}$ the North Carolina Court of Appeals ruled that a pastor whose employment had been terminated by the church could pursue claims for compensation and disability payments promised under his contract of employment and protected by state statute. The court held that "the doctrines [of 'ministerial exception' and 'ecclesiastical abstention'] do not bar courts from resolving contractual disputes not involving ecclesiastical issues and requiring only application of neutral principles of contract and statutory law."136

Tort cases offer the same analytical template. Even if the employee is ministerial, tort claims that do not involve evaluation of fitness for ministry or other ecclesiastical questions may still proceed, just as they would prior to Hosanna-Tabor. As before, sexual misconduct claims lead this pack. In Givens v. St. Adelbert Church, ${ }^{137}$ a Connecticut trial court rejected an argument that Hosanna-Tabor had altered the legal landscape with respect to claims by an alleged victim of sexual abuse against a Diocese for negligent hiring, retention, and supervision of an abusing priest at a parish school. The court allowed the negligence claim to proceed while appropriately ruling that the First Amendment required dismissal of a claim for spiritual harm. ${ }^{138}$ And in Bohnert v. Roman Catholic Archbishop of San Francisco, ${ }^{139}$ a female former schoolteacher in a Catholic all-boys high school sued the Archdiocese for intentionally inflicting emotional distress and maintaining a hostile work environment, forbidden by federal and state law, by failing to correct persistent sexual harassment by stu-

${ }^{133} I d$. at $614-15$.

${ }^{134} I d$. at 615-21.

135786 S.E.2d 358, 360 (N.C. Ct. App. 2016).

${ }^{136} I d$. We discuss questions of this sort in Lupu \& Tuttle, supra note 10, at 14444, 152-54. See also Shannon v. Mem'l Drive Presbyterian Church, 476 S.W.3d 612, 618 (2015) (Tex. Ct. App. 2015) (holding that contract and tort claims against former employer for disparaging comments to new employer not barred by ministerial exception or ecclesiastical abstention doctrines).

${ }^{137}$ No. HHDCV126032459S, 2013 WL 4420776, at *7-9 (Conn. Super. Ct., July $25,2013)$.

${ }^{138} \quad$ Id. at $* 9$.

139136 F. Supp. 3d 1094 (N.D. Cal. 2015). 
dents. A federal district court ruled that the teacher's claims presented triable issues of fact with respect to her statutory and tort claims. ${ }^{140}$

The pattern revealed in these decisions-in state and federal courts, over a period of over four years-is vivid, and strongly reinforces our analysis of Hosanna-Tabor and its jurisprudential provenance. HosannaTabor has changed nothing in the relevant law beyond offering some particularized guidance for courts to employ in deciding who is a ministerial employee. ${ }^{141}$ The immunity associated with the ministerial exception extends no further than questions of fitness for ministry. These are "ecclesiastical questions," beyond civil jurisdiction. Whether this immunity is identified as deriving from the Establishment Clause, the Free Exercise Clause, or the First Amendment's Religion Clauses acting in unison, is a matter of indifference to us. What does matter is a focused understanding of what the relevant principles do and do not entail.

Nothing in our analysis should come as a surprise. Hosanna-Tabor extended a very longstanding recognition that the Constitution precludes judicial determination of ecclesiastical questions. The unanimity of decision in Hosanna-Tabor is thus completely unmysterious; the decision fully corroborates the preexisting legal norm, and successfully points lower courts toward continuity in maintaining it.

We expect that this conclusion, pedestrian as it may seem, will disappoint those who want to expand Hosanna-Tabor into a platform for a broad doctrine of religious institutional autonomy; ${ }^{142}$ or who want to rerationalize the ministerial exception as an element of freedom of association, available without regard to religious character; ${ }^{143}$ or who see the ministerial exception as a product of patriarchal wrongdoing. ${ }^{144}$ Part IV of

${ }^{140} I d$. at 1116-25 (finding that Title VII claims and tort claims present triable issues of fact). The court discussed, but did not decide, whether Ms. Bohnert-a science teacher with occasional responsibilities for spiritual formation-qualified as a ministerial employee. Id. at 1114-15. The court also left ambiguous the question of whether any of the substantive claims would be affected if Ms. Bohnert did so qualify. Id. at 1115-16. After the district court denied summary judgment for the Archdiocese, in light of the disputed questions of fact remaining, the parties settled the case. See Nicholas Iovino, Teacher's Spat over Up-Skirt Photos Settled, Courthouse News SERv. (Nov. 18. 2015), http://www.courthousenews.com/2015/11/18/ teachers-spat-over-up-skirt-photos-settled.htm. The Ninth Circuit, in which the Bohnert case arose, has held that ministerial status is not a bar to damage claims for sexual harassment. Elvig v. Calvin Presbyterian Church, 375 F. 3d. 951, 953, 969 (9th Cir. 2004); Bollard v. Ca. Province of the Soc'y of Jesus, 196 F.3d 940, 949 (9th Cir. 1999).

${ }^{141}$ The Supreme Court's multi-factor approach in Hosanna-Tabor is somewhat different from the approach that some circuit courts had used in earlier cases. See Cannata v. Catholic Diocese of Austin, 700 F.3d. 169, 176 (5th Cir. 2012) (explaining the change in approach required by Hosanna-Tabor).

${ }^{142}$ See infra Part IV.A.

${ }_{143}$ See infra Part IV.B.

${ }^{144}$ See infra Part IV.C. 
the paper is addressed to scholars in each of those academic groups, because they alone-not the Supreme Court or the lower courts-are the source of polarization over the wisdom and scope of the unanimous opinion in Hosanna-Tabor.

\section{HOSANNA-TABOR AND ITS DISCONTENTS}

As Part III explains, Hosanna-Tabor is constitutionally sound. Had the opinion rejected the concept of a ministerial exception, the Court would have radically departed from longstanding constitutional norms. Nevertheless, scholars have exhibited intense and quite divergent disagreement about the decision's result and reasoning.

Despite the breadth of this disagreement, canvassed later in this Part IV, scholars have converged on one theme in the debate about HosannaTabor-that is, the significance of Employment Division v. Smith. In light of contemporary conversations about the Religion Clauses, this focus is completely understandable. One conventional (though distorted) account of free exercise law is that it was fiercely protective of religious liberty from 1963 until the spring of 1990, when Smith — without warningstripped away most of that protection. ${ }^{145}$ Smith restored the longstanding status quo ante, from the Court's earliest encounter with the Free Exercise Clause in $1878^{146}$ through the early 1960s. Nonetheless, the political reaction to Justice Scalia's opinion in Smith was swift and intense. This led Congress to enact the Religious Freedom Restoration Act ("RFRA") of $1993,{ }^{147}$ purportedly designed to "restore" the pre-Smith law dating from 1963 onward. RFRA has kept very much alive a debate about the necessity, wisdom, and constitutional imperative of religious exemptions.

As a result, many scholars who have commented on Hosanna-Tabor have concentrated on its relationship to Smith. The Court's woefully inadequate explanation of why Smith is not fatal to the ministerial exception inevitably magnified that attention. For example, Professor McConnell published an essay on Hosanna-Tabor in which he praised the result, argued that it rested on historical grounds, and suggested that overruling Smith would have been the best and most direct path to the ministerial exception. ${ }^{148}$ Professor McConnell's essay does not so much as mention or cite the "ecclesiastical question" decisions on which HosannaTabor expansively and explicitly relied. That, we might say, is Smith-tunnel vision in the extreme.

${ }^{145}$ See, e.g., Douglas Laycock, The Remnants of Free Exercise, 1990 Sup. CT. Rev. 1.

${ }^{146}$ Reynolds v. United States, 98 U.S. 145, 162-67 (1878) (holding that the Free Exercise Clause protects freedom of religious belief but does not protect religiously motivated action against laws prohibiting bigamy). Reynolds is cited with approval in Emp't Div. v. Smith, 494 U.S. 872, 879 (1990).

${ }_{147} 42$ U.S.C. $\$ \S 2000$ bb to bb-4(2) (2012).

148 McConnell, supra note 45, at 823. 
Professor DeGirolami, seemingly more resigned to current legal circumstances, has written an entire essay on the contrast between Smith and Hosanna-Tabor. He argues that Smith was a disaster for religious freedom, and that Hosanna-Tabor is too little and too late to provide much of a correction to the damaged law of religious exemptions. ${ }^{149}$ All that is left, he says, is "free exercise by moonlight"-dimly lit and offering little grounds for hope of a resurgence of a spirit of religious accommodation. ${ }^{150}$

Scholars who approve of Smith seem similarly trapped by the preSmith narrative of Free Exercise exemptions. Professor Gedicks, for example, has criticized Hosanna-Tabor for "doctrinal incoherence." ${ }^{151} \mathrm{He}$ claims that the Court was pursuing an internally contradictory approach by simultaneously embracing Establishment Clause norms, which preclude balancing, and Free Exercise norms, which invite balancing under the pre-Smith case law. ${ }^{152}$

We fully recognize that Smith, and the pre-Smith regime, have had this grip on the consciousness of religious-freedom lawyers since the day it was decided. But, in considering Hosanna-Tabor, their focus on Smith is at best unhelpful, and at worst a mind-clouding distraction. In sharp contrast, our account of Hosanna-Tabor recognizes no role at all for Smith. The ministerial exception problem is a subset of a completely distinct class of controversies, in which disputes involve "strictly and purely ecclesiastical questions." The Hosanna-Tabor Court explicitly and exclusively relied on Watson, Kedroff, and Milivojevich, three of the leading decisions in that distinct line.

149 DeGirolami, supra note 94, at 123-29; see also Marc O. DeGirolami, Constitutional Contraction: Religion and the Roberts Court, 26 Stan. L. \& Pol'y Rev. 385, 404 (2015).

${ }^{150}$ That spirit, DeGirolami suggests, has been damaged by the movement to protect LGBT rights and women's reproductive rights. DeGirolami, supra note 94, at 131-44. He refuses to acknowledge that concern for third-party harms is a longstanding limitation on permissive accommodations-see Estate of Thornton v. Caldor, Inc., 472 U.S. 703, 710 (1985)—and that religious accommodations for business firms, even when they inflict material or dignitary harms on others, represent a radical extension of the appropriate scope of permissive religious accommodation. For rich discussion of these themes, see Martin Lederman, Reconstructing RFRA: The Contested Legacy of Religious Freedom Restoration, 125 YALE L.J. F.416, 417 nn.110-11 (2016); James Oleske, Jr., The Evolution of Accommodation: Comparing the Unequal Treatment of Religious Objections to Interracial and Same-Sex Marriages, 50 HaRv. C.R.-C.L. L. Rev. 99 (2015); Elizabeth Sepper, Reports of Accommodation's Death Have Been Greatly Exaggerated, 128 HARv. L. REv. F. 24 (2014).

${ }^{151}$ Gedicks, Narrative Pluralism and Doctrinal Incoherence, supra note 22.

${ }^{152} I d$. at 421-31. Professor Gedicks's agreement with Smith is expressed richly in Frederick Mark Gedicks, An Unfirm Foundation: The Regrettable Indefensibility of Religious Exemptions, 20 U. Ark. Little Rock L. Rev. 555 (1998). 
Cases like Yoder and Smith, which involve claims of exemption for religiously motivated conduct from general secular norms, belong to a different set altogether. There is no mystery about this separation of sets; the Smith opinion asserts it straightforwardly in its distinction of the ecclesiastical question cases. ${ }^{153}$ So the Court in Hosanna-Tabor might wisely have written: "As we noted in Smith, its antiexemption principle does not apply when the case requires resolution of a 'strictly and purely' ecclesiastical question, including fitness for ministry or the structure of religious governance." This would have been far clearer than Hosanna-Tabor's mystifying pseudo-distinction between "outward physical acts" (taking peyote as a sacrament) and internal decisions that "affect[] the faith and mission" of the church (in Hosanna-Tabor, firing Cheryl Perich).

Without question, lines must be drawn with respect to which cases involve ecclesiastical questions and which do not. Moreover, courts must have the authority to draw the lines between ecclesiastical and secular judgments. If that power were granted to religious communities, they would naturally and inevitably draw that line in self-interested ways.

Whether Hosanna-Tabor presented a "strictly and purely" ecclesiastical question was not self-evident. Watson, Kedroff, and Milivojevich involved questions of private ordering within a religious community, so the "pure" quality of the ecclesiastical questions was easy to see. In contrast, Hosanna-Tabor touches on a matter of regulation in service of government policies against discrimination. Institutions that violate such policies impose significant negative externalities, including job loss and fear of retaliation against those who complain to the government about misbehavior by church officials. Accordingly, the relevant questions do not appear at first glance to be "purely ecclesiastical."

A more careful look produces a different impression. It is true that under most circumstances, application of regulatory norms to church conduct will not implicate ecclesiastical questions. Instead, such enforcement will pit secular regulations against religious concerns, and Smith will apply. In such conflicts, Smith teaches that generally applicable regulatory norms must prevail against free exercise objections. When clergy seek a determination that an adverse job action is unlawful, however, courts will frequently have to confront the ecclesiastical question of fitness for ministry, whether of a class or a particular person. Because questions of fitness for ministry are beyond the constitutional competence of the state, regulatory concerns cannot be constitutionally applied in this context. This is a matter of church-state boundary drawing, which

${ }^{153}$ Emp't Div. v. Smith, 494 U.S. 872, 877 (1990) (distinguishing Watson, Kedroff, and Milivojevich because they involve the government lending "its power to one or the other side in controversies over religious authority or dogma"). 
Smith fully accepts, and not a matter of interest balancing, which Smith rightly rejects. ${ }^{154}$

Had the Court followed that line of reasoning, it would have remained true to all relevant lines of cases, rather than suggesting a contradiction between them. Moreover, it would have reaffirmed that it is judicial business to decide which questions are "strictly and purely ecclesiastical," in the same way it is within the judicial authority to decide who acts as a communicator of the faith, and therefore fits the ministerial exception. Courts mark these boundaries and then abstain with respect to matters within them. Smith is correct, ${ }^{155}$ and Hosanna-Tabor is likewise correct.

Our explanation of the relationship between Smith and HosannaTabor suggests another reason why both friends and foes of HosannaTabor are overly focused on Smith and the historical arc of free exercise principles. We think Hosanna-Tabor is best justified as an instance of the First Amendment principle that the state may not adjudicate "strictly and purely ecclesiastical questions." This principle primarily emerges from considerations of government competence, rather than concerns of individual rights. Yet most of the scholars whose work we discuss in this Part seem indifferent at best to this line of thought. Those who support a free exercise-centered approach to Hosanna-Tabor are perhaps concerned that the "ecclesiastical question" doctrine is much narrower protection for religious entities than they prefer. ${ }^{156}$ Those who condemn Hosanna-Tabor as unsupported by contemporary free exercise principles do not want establishment clause concepts coming to the rescue of the ministerial exception.

Hosanna-Tabor's discontents operate from premises very different from ours. The final three Sections of this Part evaluate the varying approaches of these critics and explain why they are all, in different ways, contrary to deep commitments within our constitutional tradition.

154 Id. at $884-87$

${ }^{155}$ In Secular Government, Religious People, we defend Smith primarily on grounds of lack of constitutional competence on the part of judges to decide the significance of religious burdens and weigh them against secular interests. LUPU \& TUTTLE, supra note 76, at 195-201; see also Ira C. Lupu, Hobby Lobby and the Dubious Enterprise of Religious Exemptions, 38 HARV. J.L. \& GENDER 35 (2015) (criticizing all general regimes of religious exemptions as invitations to arbitrary judgment and unprincipled manipulation).

${ }^{156}$ In addition, some reflexively dismiss Establishment Clause principles as unfriendly to religion. McConnell, supra note 45, at 824 (saying the Establishment Clause is "an unlikely avenue for upholding a religious exemption from the antidiscrimination laws"). But see id. at 834 (suggesting Professor Esbeck's article (Carl H. Esbeck, Establishment Clause Limits on Governmental Interference with Religious Organizations, 41 Wash. \& LeE L. Rev. 347 (1984)) "might serve as a jumping-off point for further development" of an Establishment Clause basis for Hosanna-Tabor). 


\section{A. The Expanders-Freedom of the Church and Implied Consent Theory}

As earlier Sections of this Article explain, we think Hosanna-Tabor is correctly decided and that it rests unambiguously on a First Amendment norm of judicial disability to decide "strictly and purely ecclesiastical" questions. Many of the scholars discussed in this Section agree that $\mathrm{Ho}^{-}$ sanna-Tabor is sound, and that religion-specific grounds explain it. But these scholars part company with us concerning the respective roles of each religion clause, and the relevant methodology of decision. We call this group the "Expanders," because they believe that Hosanna-Tabor confirms the idea that religious entities possess a much broader constitutional immunity from regulation than the "ecclesiastical question" doctrine would support. The "Expanders" fall into two distinct groups: 1) institutional theorists and 2) implied consent theorists.

\section{The institutionalists}

The institutionalists argue that the First Amendment's Religion Clauses support a general theory of "freedom of the church." 157 Some go

${ }^{157}$ The earliest iteration of a church autonomy theory is found in Douglas Laycock, Towards a General Theory of the Religion Clauses: The Case of Church Labor Relations and the Right to Church Autonomy, 81 Colum. L. Rev. 1373 (1981). Professor Laycock later modified some of his views in Douglas Laycock, Church Autonomy Revisited, 7 GEO. J.L. \& Pub. Pol'y 253 (2009). Several of the chapters in The Rise of Corporate Religious Liberty advance and defend a variety of theories of church freedom. These include Richard W. Garnett, The Freedom of the Church: (Toward) an Exposition, Translation, and Defense, in The Rise of Corporate Religious Liberty 39 (Micah Schwartzman et al. eds., 2016); Zoe Robinson, Hosanna-Tabor After Hobby Lobby, supra at 173; Steven D. Smith, The Jurisdictional Conception of Church Autonomy, supra at 19; see also Kathleen Brady, Religious Organizations and Free Exercise: The Surprising Lessons of Smith, 2004 BYU L. Rev. 1633; Patrick McKinley Brennan, Differentiating Church and State (Without Losing the Church), 7 Geo. J.L. \& Pub. PoL'y 29 (2009); Perry Dane, Master Metaphors and Double-Coding in the Encounters of Religion and State, 53 SAN Diego L. Rev. 53 (2016); Paul Horwitz, Churches as First Amendment Institutions: Of Sovereignty and Spheres, 44 Harv. C.R.-C.L. L. Rev. 79 (2009); see also Perry Dane, Master Metaphors and DoubleCoding in the Encounters of Religion and State, 53 SAN Diego L. Rev. 53 (2016); John Inazu, The Freedom of the Church (New Revised Standard Version), 21 J. Contemp. Legal Issues 335 (2013); Zoe Robinson, What Is a "Religious Institution"?, 55 B.C. L. Rev. 181 (2014). For a detailed exploration of the relationship between the ministerial exception and "freedom of the church," see Gregory A. Kalscheur, Civil Procedure and the Establishment Clause: Exploring the Ministerial Exception, Subject Matter Jurisdiction, and the Freedom of the Church, 17 WM. \& MARY BILL RTs. J. 43 (2008). The editors of The Rise of Corporate Religious Liberty are complicit in the too-casual assertion that HosannaTabor supports theories of institutional autonomy. See Chad Flanders et al., Introduction to The Rise of Corporate Religious Liberty, supra at xiii, xvi ("Proponents of freedom of the church found their views vindicated to a surprising extent by the Supreme Court's unanimous decision in Hosanna-Tabor."). For an explanation of why these theories have become prominent of late, see Paul Horwitz \& Nelson Tebbe, Religious Institutionalism: Why Now?, in The Rise of Corporate Religious Liberty, supra at 221. Others recognize the trendy distinction between institutional and individual rights, but lament rather than praise it. For example, 
so far as to assert that religious entities possess a form of sovereignty, separate and apart from that of the state. ${ }^{158}$ All of the institutionalists assert that religious entities have a constitutional right to control their internal affairs that is greater than the rights afforded to comparable secular entities. All of these scholars see ministerial employment as a quintessentially internal matter, and thus regard Hosanna-Tabor as an easy case for constitutional protection of church autonomy. ${ }^{159}$

Hosanna-Tabor does not openly reject a broad theory of religious institutional autonomy, so these approaches (unlike the others, considered in Part IV.B. and IV.C.) cannot be dismissed out of hand in explaining the decision. Nevertheless, we think none of them are constitutionally sound, workable, or consistent with the unanimous reasoning in Hosanna-Tabor. ${ }^{160}$

At their roots, all theories that assign broad and unique exemption rights to religious entities are constitutionally flawed. In Against Religious Institutionalism, ${ }^{161}$ Richard Schragger and Micah Schwartzman have written the most comprehensive critique of the various scholarly theories of freedom of the church and the related idea that churches represent "separate sovereignties," free of state control over important aspects of their operations. We cannot reflect on all of their arguments in the space allotted here, but a few central points deserve emphasis.

First, the model of "freedom of the church" is based on a singular church, one that claims sovereignty over all matters within its ambit of concern, spiritual and otherwise. ${ }^{162}$ Our world bears no resemblance to medieval Europe, in which Popes of a singular church contended with emperors and kings over spheres of authority. ${ }^{163}$ Freedom of the church in the United States would have to mean equal freedom for all religious

Professor Gedicks criticizes Hosanna-Tabor for recognizing free exercise rights for institutions without weighing competing state interests, thereby producing a free exercise right "on steroids." Gedicks, Narrative Pluralism and Doctrinal Incoherence, supra note 22, at 421-33. See also Gregory Magarian, The New Religious Institutionalism Meets the Old Establishment Clause, in The Rise of Corporate Religious Liberty, supra at 441, 446-47.

${ }^{158}$ See, e.g., Smith, supra note 157, at 29-31. Smith invokes the concept of "sovereignty," but his prior qualifications make the ultimate meaning of the term very murky. Id. at 20-27. See also Dane, supra note 157.

${ }^{159} I d$. at 27; Garnett, supra note 157, at $49 \&$ n. 69.

${ }^{160}$ The concurring opinion of Justice Thomas in Hosanna-Tabor is the only one that comes close to embracing a broad theory of deference to religious institutions in designating which employees should be deemed as ministerial. No other Justice joined him in this opinion. Hosanna-Tabor Evangelical Lutheran Church \& Sch. v. EEOC, 565 U.S. 171, 196-98 (2012) (Thomas, J., concurring).

${ }^{161}$ Richard Schragger \& Micah Schwartzman, Against Religious Institutionalism, 99 VA. L. REv. 917 (2013).

${ }^{162}$ Id. at $926-28$.

${ }^{163} I d$. 
communities, including (to mention but a few) Catholics, Protestants, ${ }^{164}$ Jews, Muslims, Wiccans, and Scientologists. And it would similarly mean that all religious associations would have some unspecified measure of control over internal affairs, including employment, greater than that afforded all secular associations, nonprofit or otherwise. American law does not just fail to support any such proposition; it emphatically rejects it. ${ }^{165}$

Second, the notion that any private entities should be afforded sweeping authority, free of state supervision, over persons and their property is thoroughly inconsistent with liberal democratic order. In our system, temporal power over persons and things must be exercised in ways that are subject to public accountability under that democratic regime. ${ }^{166}$ Our constitutional arrangements do not permit the delegation of coercive and unreviewable authority to families or other private associations, whether these associations are religious or not. ${ }^{167}$

The institutionalists' invocation of the autonomy, freedom, and sovereignty of religious entities is thus vastly overstated. Schwartzman and Schragger offer a compelling critique. But they, like their targets, too narrowly focus on the character of individuals and institutions as rightsbearers. Jurisdictional arguments are indeed involved in the controversy over the ministerial exception, but these arguments arise primarily from the Establishment Clause. ${ }^{168}$ The Establishment Clause separates power over temporal matters, belonging to the state, from authority over spiritual concerns, which the Constitution removes from the state. ${ }^{169}$ The

${ }^{164}$ See Inazu, supra note 157, at 362-66 (discussing problems of translating freedom of the church from Catholic to Protestant versions).

${ }^{165}$ Even before the decision in Smith, the Supreme Court unanimously rejected a claim by the Tony \& Susan Alamo Foundation for a Free Exercise exemption to the Fair Labor Standards Act. Tony \& Susan Alamo Found. v. Sec'y of Labor, 471 U.S. 290 (1985). The "Expanders" all seem reluctant to discuss this decision, perhaps because of the unsavory reputation of the Foundation and its founder, Tony Alamo. See Alamo Christian Foundation, https://en.wikipedia.org/wiki/Alamo_Christian_Foundation (last visited Dec. 20, 2016); see also United States v. Lee, 455 U.S. 252, 254 (1982) (holding that the Free Exercise Clause does not authorize Amish employers to withdraw their Amish employees from the Social Security system).

${ }^{166}$ Schragger \& Schwartzman, supra note 161, at 939-45; see also Jean L. Cohen, Freedom of Religion, Inc.: Whose Sovereignty?, 44 Neth. J. Legal Phil. 169, 171 (2015), http://papers.ssrn.com/sol3/papers.cfm?abstract_id=2676141 (arguing that the recent strains of "freedom of religion' discourse proliferating in the US and influencing the Court involve[] the assertion of privileges and immunities from civil and constitutional law, not equal rights or fair treatment under that law, thus undermining rather than being the paradigm of liberal rights, and threatening the achievements of democratic constitutionalism").

${ }^{167}$ Indeed, when one state attempted to delegate such power to religious entities, the Supreme Court held (8-1) that the delegation was a violation of the Establishment Clause. Larkin v. Grendel’s Den, Inc., 459 U.S. 116 (1982).

${ }_{168}$ LupU \& TutTle, supra note 76, at 16-20.

${ }^{169} I d$. at 19-29. 
prohibition on state resolution of "strictly and purely ecclesiastical questions" emerges from precisely such a distinction, and not from any theory of church sovereignty. Because fitness for ministry pertains to spiritual matters, it remains the exclusive province of religious authorities. Even within that construct, however, the state retains the authority to decide which positions are ministerial and therefore beyond the reach of some forms of regulatory power. The ministerial exception is thus supportive of church freedom, but is not a product of church freedom. ${ }^{170}$

\section{Implied consent theorists}

The second group of "Expanders" argues from individualist rather than institutional premises. They contend that members of religious communities give implied consent to policies that might otherwise be illegal, and that the law should give full effect to that consent. ${ }^{171}$ Quite unlike the institutional theories, which have resonances of both the Catholic and LDS tradition, the implied consent theories implicitly rely on concepts of voluntarism that are closely related to certain forms of Protestantism.

As Professor Hill has recently argued, ${ }^{172}$ however, participation in such communities may be driven by forces that vitiate full assent to institutional policies. For participants, involvement may derive from circumstances of birth or early childhood when awareness of institutional policies will be slim or none. ${ }^{173}$ Membership subsequently arises from some act of voluntary consent, but that tends to happen in early adolescence, an age at which we do not treat individuals as competent to waive important legal rights. Moreover, members of any age may be unaware of

${ }^{170}$ As should be obvious from Parts I-III, supra, and Part IV.B, infra, we do not agree with Schragger and Schwartzman's attempt to force the ministerial exception into a more general, rights-based framework of freedom of conscience. Schragger \& Schwartzman, supra note 161, at 974-77 (indicating hesitation over the specific result in Hosanna-Tabor and attributing whatever is normatively attractive in the ministerial exception to freedom of conscience of individuals, who are free to associate and select leaders in secular and religious entities alike). For reasons developed in Part IV.B, infra, we do not believe that constitutional principles of associational freedom should extend into the employment relationship, as the ministerial exception does.

${ }^{171}$ Professors Helfand and Lund are prominent proponents of such theories. See Michael A. Helfand, Religious Institutionalism, Implied Consent, and the Value of Voluntarism, 88 S. CAL. L. REv. 539 (2015); Christopher Lund, Free Exercise Reconceived: The Logic and Limits of Hosanna-Tabor, 108 N.W. L. Rev. 1183 (2013). For these scholars, like those in the institutionalist group, a reading of Hosanna-Tabor that takes religiously identified employers outside the ambit of Smith is salutary. Helfand, supra at 548-49 (arguing that Smith unsettled the free exercise basis of the ministerial exception and that Hosanna-Tabor has restored that basis).

172 B. Jessie Hill, Change, Dissent, and the Problem of Consent in Religious Organizations, in The Rise of Corporate Religious Liberty, supra note 157, at 419.

${ }^{173} I d$. at 426-28. 
significant institutional policies. Implied consent is a strong and unjustified inference to be drawn from membership, standing alone.

The implied consent theorists do not limit their attention to the membership role. They focus broadly on the waiver of rights held by all employees, ministerial or otherwise, of religious institutions. Indeed, that breadth of the theory is one of its more troubling defects. Religious institutions employ a very substantial number of individuals in an extremely wide variety of positions. A doctrine that uses the concept of implied consent to strip employees of substantial legal rights deeply undermines important public policies with no assurance whatsoever that employees even understand the rights at issue, much less the implications of forgoing them. ${ }^{174}$

Even with respect to employees in ministerial roles, the theory of implied consent is defective. Although it is possible to imagine circumstances in which a cleric and a congregation bargain with respect to terms of employment, including the applicability of certain background norms of employment law, very few ministerial employment relationships will be so dependent on the bilateral agreement of the employer and employee. Almost invariably, a more complex set of ecclesiastical authorities will have some level of involvement in the formation and termination of ministerial employment. The terms of the engagement will be shaped by canon law or comparable religious norms. Although ministerial employees voluntarily consent to ordination or other forms of entry into ministry, they almost never have the slightest opportunity to bargain over specific institutional employment policies. In these circumstances, implied consent is entirely a fiction in which the religious status of both employer and employee are doing all the work.

Moreover, implied consent theorists insist on describing HosannaTabor as predominantly a free exercise decision in which some form of interest balancing is presumptively appropriate. ${ }^{175}$ This is a pure misread-

174 Professor Helfand apparently would extend his theory to all employees of entities with a religious character, so long as the relevant departure from legal norms is made known to employees in advance. Helfand, supra note 171, at 542 ("[A] focus on implied consent entails a context-sensitive inquiry into whether the institution was sufficiently open and obvious about its religious objectives....”). And he would include for-profit businesses in the set of entities capable of manifesting a religious character. Id. (" $[\mathrm{T}]$ he inquiry into whether an institution is ... religious ... has nothing to do with it being a for-profit or nonprofit institution . . .."); $i d$. at 574-78 (suggesting the possibility that the outcome in Burwell v. Hobby Lobby Stores, Inc. is ultimately defensible on the basis of implied consent of the company's employees).

${ }^{175}$ Id. at 549-53 (suggesting that free exercise-based strict scrutiny, involving interest balancing, should apply to cases like Hosanna-Tabor); Lund, supra note 171, at 1189 (suggesting that Hosanna-Tabor "aligns . . . with Sherbert and Yoder"); id. at 1203 ("[A]bsent some compelling government interest, the First Amendment precludes insiders from suing their churches over matters of significant religious concern.”). In other works, both Helfand and Lund reject the notion that courts are forbidden from 
ing, rather than an interpretation, of Hosanna-Tabor. The bar on state decisions of ecclesiastical questions has never included interest balancing in any context, ministerial exception or otherwise. And, as explained in Part II above, Hosanna-Tabor unanimously and explicitly repudiates such a methodology.

\section{Overarching problems of application}

Even if these various defenses of constitutional privilege for religious entities were not flawed foundationally, they remain subject to criticism at the level of methodology and application. First, any theory that assigns rights to institutions based on their religious character must determine which entities qualify for such a treatment. Once we get past the obvious category of houses of worship, identifying which institutions should count as religious for these purposes becomes extremely difficult. Religiously-affiliated entities encompass those that deliver health care, ${ }^{176}$ education, housing, counseling, and a variety of other goods and services, sometimes in competition with commercial providers. As Professor Koppelman and others have argued, the criteria suggested in the academic commentary to determine which institutions constitutionally qualify as religious are highly vague. ${ }^{177}$ That indeterminacy might be tolerable if the only stakes were eligibility for some well-defined statutory privilege, like Title VII's coreligionist exemption for employers with a primary religious purpose. ${ }^{178}$ In the context of broader constitutional theories about freedom of the church, however, deep and abiding uncertainty about who qualifies for this special freedom from regulation is debilitating. ${ }^{179}$

deciding ecclesiastical questions. Michael Helfand, Litigating Religion, 92 B.U. L. REv. 493 (2013); Christopher Lund, Rethinking the "Religious Question" Doctrine, 41 PePp. L. REv. 1013 (2014). Their emphasis on individual voluntarism leads them to support the judicial enforceability of private agreements, without exclusion of religious questions that might be presented.

${ }^{176}$ The question of whether religiously affiliated health care institutions should have constitutional rights to resist state regulation is aggravated yet further by contractual arrangements with secular for-profit entities, under which religiously affiliated providers attempt to retain religiously based restrictions on service, including matters related to reproduction. For discussion of this growing phenomenon, see Elizabeth Sepper, Contracting Religion, in LAW, RELigion, AND Health in the United States (Holly Fernandez Lynch et al. eds., forthcoming 2017), http://papers.ssrn.com/sol3/papers.cfm?abstract_id=2783518.

${ }_{177}$ Andrew Koppelman, "Freedom of the Church" and the Authority of the State, $21 \mathrm{~J}$. Contemp. Leg. Issues 145, 156 (2013); Lupu \& Tuttle, Religious Exemptions and the Limited Relevance of Corporate Identity, in The Rise of Corporate Religious Liberty, supra note 157, at 374-376.

17842 U.S.C. $\$ 2000 \mathrm{e}-1$ (2012).

${ }^{179}$ Moreover, such criteria might incentivize religiously insincere arrangements by those seeking to get or remain on the constitutionally preferred side of the line. Lupu \& Tuttle, supra note 177, at 384. 
Second, even if the criteria for identifying the constitutionally preferred religious institutions were far more definite, the methodology for deciding the content of these entities' rights badly exacerbates the problem of indeterminacy. As best we can tell, for all the Expanders, that methodology takes the form of some kind of pre-Smith Free Exercise balancing of interests. ${ }^{180}$ Even if the content of that test were well-defined, the Supreme Court's experience in applying it shows its considerable plasticity. ${ }^{181}$

Perhaps the most conspicuous evidence of the indeterminacy of theories of "freedom of the church," or "implied consent," is the persistent failure of many proponents of these theories to analyze situations that seem difficult, or to identify any cases in which religious entities should lose. ${ }^{182}$ Professor Smith makes no effort whatsoever to identify such cases. ${ }^{183}$ In Professor Garnett's most recent work on freedom of the church, ${ }^{184}$ he purports to "translate" that freedom into concrete terms, but most of what he offers are legal principles that are well-recognized and do not depend in the slightest on a doctrine of "freedom of the church." ${ }^{, 185}$ Although he asserts that "freedom of the church" is a broader category than immunity from state adjudication of ecclesiastical ques-

${ }^{180}$ As Professor Lederman has demonstrated, the content of that balancing test is itself up for grabs. See Lederman, supra note 150, at 440-41.

${ }^{181}$ Lupu, supra note 155 , at 48-53.

182 Schragger \& Schwartzman, supra note 161, at 970-74 (pointing out the extreme vagueness of "freedom of the church" theorists on the particulars of what rights their theories would grant to religious entities beyond those already afforded by the prohibition of judicial resolution of ecclesiastical questions). The implied consent theorists do better than the "freedom of the church" theorists in specifying analytic approaches and recommended outcomes for particular classes of controversies. Professor Lund's work admirably canvasses a considerable variety of cases in working out his approach. See, e.g., Lund, supra note 171, at 1207-29 (discussing a range of cases involving torts, contracts, and property through the prism of implied consent to the norms of the religious community); see also Helfand, supra note 157, at 575-77 (arguing that, viewed through the prism of implied consent, Burwell v. Hobby Lobby Stores, Inc. may be correctly decided). But neither discusses the most difficult cases, including claims of sexual harassment of clergy and claims that religious authorities have negligently supervised clergy who have shown a propensity for abuse of children. The parents of these children have no authority to consent, expressly or by implication, to risks of this kind and magnitude.

${ }^{183}$ Professor Smith mentions a number of examples in his recent chapter on religious jurisdiction, but he lumps them all together and makes no effort to indicate how any of them should be approached or resolved. Smith, supra note 157, at 25-27.

${ }^{184}$ Garnett, supra note 157.

${ }^{185} I d$. at 60-62 (Freedom of the church includes prohibitions on: 1) government targeting of specific faiths; 2) government compulsion of religious observance; and 3) government decision of ecclesiastical questions). 
tions, he fails to offer a single example in which his theory would protect a religious institution in circumstances where ours would not. ${ }^{186}$

In any effort at legal theorizing, details and applications matter. In our own attempts to define the constitutional limits on judicial decision of "strictly and purely ecclesiastical questions," we have closely analyzed a wide range of particular contexts and questions. ${ }^{187}$ These include variations on the ministerial exception, ${ }^{188}$ but they also include issues of defamation, ${ }^{189}$ liability for negligent supervision of clergy who commit sexual abuse, ${ }^{190}$ and contract disputes between clergy and their employers. ${ }^{191} \mathrm{We}$ have identified easy and hard cases, and endeavored to chart an analytic path in difficult ones.

Others, whose work we have challenged in this Section, should do likewise. The most pressing questions for them to answer, in light of the problems facing courts today, include whether religious entities: 1) may be held liable for sexual harassment of employees in ministerial positions ${ }^{192}$ 2) may be held liable for negligent supervision of clergy who commit tortious acts, sexual or otherwise, against church members; ${ }^{193}$ 3)

${ }^{186} I d$. at $51 \&$ n.80. Garnett also proposes, in the name of freedom of the church, two concrete legal changes: 1) abandonment of the "so-called "endorsement test," and 2) improvement of "the version of the 'Lemon test' that is applied in publicfunding cases," so that we no longer ask whether government support advances religion but inquire instead "whether the government program....creates an institutional relationship...that is reasonably characterizable as a religious 'establishment."' Id. at 61-62. Both of these moves are quite obviously designed to weaken Establishment Clause constraints on state power to support religious causes and entities. Whether or not these are good ideas, these supposed "translations" of church freedom are not aimed at freeing "the church" from any regulatory constraints. Instead, they represent expansions of state power to support those entities and their missions. Moreover, in at least some contexts, those expansions of state power threaten rather than protect the religious freedom of individuals. See, e.g., Town of Greece v. Galloway, 134 S. Ct. 1811 (2014). Why the Religion Clauses should be read to reduce individual religious freedom, while expanding state power to promote religion and the freedom of religious institutions, is not something the defenders of these theories are quick to acknowledge or explain.

${ }^{187}$ See generally Lupu \& Tuttle, supra note 10; see also Ira C. Lupu \& Robert W. Tuttle, Same Sex Family Equality and Religious Freedom, 5 Nw. J.L. \& Soc. PoL'y 274, 284 85 (2010) (distinguishing between secular and ecclesiastical definitions of marriage, and arguing that the state may specify the former but not the latter, which is reserved for religious communities).

${ }^{188}$ Lupu \& Tuttle, supra note 10, at 138-46.

189 Id. at $155-60$.

${ }^{190}$ Lupu \& Tuttle, supra note 105, at 1851-56, 1851 n.243 (citing decisions allowing claims of negligent supervision to go forward).

${ }_{191}$ Lupu \& Tuttle, supra note 10, at 152-54.

${ }^{192}$ See, e.g., Black v. Snyder, 471 N.W.2d 715, 718 (Minn. Ct. App. 1991); McKelvey v. Pierce, 800 A.2d 840, 844 (N.J. 2002).

${ }^{193}$ See, e.g., Enderle v. Trautman, No. CIV.13-01-22, 2001 WL 1820145 (D.N.D. Dec. 3, 2001); Moses v. Diocese of Colo., 863 P.2d 310 (Colo. 1993). 
should be constitutionally free from prohibitions on sex, age, or disability discrimination, or from legislative fair labor standards, with respect to non-ministerial employees; ${ }^{194}$ and 4) should be free to terminate employees, ministerial or otherwise, in violation of contractual terms that do not involve evaluation of fitness for ministry. ${ }^{195}$

If their theories produce results identical to ours, the differences among all these ideas may be purely rhetorical. On the other hand, if some theories are designed to produce a wider form of autonomy for religious entities than the "ecclesiastical question" doctrine, their proponents should be prepared to defend those specific results.

If they remain mute in the face of this challenge, however, it will suggest that they have no good response to the problem of indeterminacy, or are simply unwilling to oppose the interests of religious entities. Either way, courts should continue to reject their theories as constitutionally infirm. ${ }^{196}$ It is impossible to believe that all of the Hosanna-Tabor Justices were operating on theories so flawed.

\section{B. The Re-Rationalizers-Secular Freedom of Association}

A number of critics of Hosanna-Tabor assert that its principal defect is that the ministerial exception protects only religious employers. To these scholars, religious institutions and religiously motivated actors are not entitled to constitutional treatment superior to that afforded to their secular counterparts. ${ }^{197}$

194 For example, would they question the result in EEOC v. Fremont Christian Sch., 781 F.2d 1362, 1365-70 (9th Cir. 1986), which held that Title VII prohibits a religious employer from paying men more than women, on the religious ground that only men can be the head of a household?

${ }^{195}$ Kant v. Lexington Theological Seminary, 426 S.W.3d 587, 590 (finding that courts may adjudicate legality of dismissal of tenured theology professor on ground of financial exigency).

${ }^{196}$ As we note in Part III, the lower court decisions, pre- and post-Hosanna-Tabor, all line up with our view. Courts recognize no general doctrine of church autonomy for "internal matters." Whether or not the case involves a ministerial employee, the relevant question is whether the issue involves ecclesiastical determinations; if and only if it does, the claim is barred. See, e.g., Bohnert v. Roman Catholic Archbishop of S.F., 136 F. Supp. 3d 1094, 1114-15 (N.D. Cal. 2015) (explaining that teacher's claims of sexual harassment may go forward because they present no questions of her fitness for religious duties); McCallum v. Billy Graham Evangelistic Ass'n, No. 3:09CV381RLV, 2012 WL 4756061, at*5-7 (W.D.N.C, Oct. 5, 2012) (rejecting church autonomy defense regarding claim of race discrimination by nonministerial employee); Buscetto v. St. Bernard High Sch., No. CV116011089, 2014 WL 4494362, at *3 (Conn. Super. Ct., July 25, 2014) (rejecting "entanglement" defense in case involving dismissal of whistleblower regarding misuse of funds).

${ }^{197}$ This view is strenuously urged by Lawrence G. Sager, Why Churches (and Possibly, the Tarpon Bay Women's Blue Water Fishing Club) Can Discriminate, in The Rise of Corporate Religious Liberty, supra note 157, at 77 and Schragger \& 
In the particular context of the ministerial exception, the argument takes the form that all associations, religious or secular, should be equally bound (or not) by the law of nondiscrimination in employment. Hosanna-Tabor involved an elementary school teacher with relatively limited responsibilities for religious instruction. ${ }^{198}$ And the precise question was whether the school was free to ignore laws about retaliation against those who complain of disability discrimination by an employer. ${ }^{199}$ Is there a remotely plausible claim of a constitutional right of freedom of association, not specific to religion, in these circumstances?

Lawrence Sager is the leading advocate for such a rights-based theory, applicable to the problem in Hosanna-Tabor. In his earlier work with Christopher Eisgruber, ${ }^{200}$ and in a recent book chapter, ${ }^{201}$ Professor Sager has asserted a theory of close (or intimate) association, available to members of secular and religious groups alike, which he claims is an appropriate constitutional rerationalization of Hosanna-Tabor. Sager's work is influential, and others in the academy may find his argument seductive, so it seems worth the effort for us to point out its profound flaws.

Sager begins by offering a proposition which he claims "enjoy[s] very broad-if not universal-assent: As a matter of political morality, the Catholic Church is entitled to insist that its priests be male without interference from the state." ${ }^{202}$ Why would that proposition be a widely shared matter of political morality? In fact, within the Church, there is considerable dissent about the exclusion of women from the priesthood. ${ }^{203}$ That the priesthood is patriarchal is a matter of both ancient practice and equally ancient criticism. We suspect that a significant number of Catholics would be at least somewhat gratified if the state insisted that an allmale priesthood is contrary to strong public policy, and removed tax exemptions from religious entities that bar women from clergy status. ${ }^{204}$

Schwartzman, supra note 161 . This was the approach taken unsuccessfully by the Government in its brief in Hosanna-Tabor. Hosanna-Tabor Evangelical Lutheran Church \& Sch. v. EEOC, 565 U.S. 171, 189-90 (2012). Schragger and Schwartzman do not offer a view of whether Hosanna-Tabor was correctly decided, though it is difficult to see how their individual conscience-based premises could possibly align them with the Court. Schragger \& Schwartzman, supra note 161, at 975.

198 Hosanna-Tabor, 565 U.S. at 178.

199 Id. at 176-77.

200 See Christopher L. Eisgruber \& Lawrence G. Sager, Religious Freedom AND THE Constitution (2007).

201 Sager, supra note 197, at 77.

${ }^{202}$ Id.

${ }^{203}$ There is an active movement within the Catholic Church for the ordination of women as priests. See About Us, Women's Ordination Conf., http://www. womensordination.org/about-us/ (last visited Dec. 20, 2016).

${ }^{204}$ In Bob Jones Univ. v. United States, 461 U.S. 574 (1983), the Supreme Court upheld the revocation of the tax exempt status of a university that prohibited interracial marriage or dating among its students. Racial distinctions are frequently 
So the right to maintain an all-male priesthood is not necessarily a widely held proposition of political morality, but it remains a constitutional norm, unanimously affirmed in Hosanna-Tabor. Sager suggests four possible explanations for the church's right to discriminate. Two of them involve assertions of religious autonomy-either as a general proposition related to religiously-motivated action, or as a more limited right of autonomy held by religious institutions. ${ }^{205}$ Following the argument that he makes in more extended form in his coauthored book, he rejects these on the grounds that religion is not entitled to this kind of special treatment as compared with its secular counterparts. ${ }^{206}$

Our sharp disagreement with Sager arrives when he dismisses his third suggested explanation, which focuses on state decisions involving ecclesiastical questions. He characterizes this category of cases as implicating the state's "obligation of neutrality among religious faiths, ${ }^{207}$ an obligation which he then describes as an antidiscrimination or antidisparagement principle. And he breezily brushes it aside as an "indirect" way of protecting what he calls the "first order" principle that it is "wrong ... to tell the Catholic Church that it must hire women priests."

Sager completely misunderstands the prohibition on state decision of ecclesiastical questions. This is precisely the ground of Hosanna-Tabor, and it does not rest on a concern for disparagement or discrimination. Instead, it rests on a constitutional denial of the state's competence to decide a certain class of questions, such as qualifications for ordination, or the structure of church authority. ${ }^{209}$ For a state to have an exclusively secular character, some questions must be outside its jurisdictional boundaries. In order to decide which questions those are, religion must

seen as far more odious than those based on gender, and the Bob Jones case involved a university and its students, not a church and its criteria for ordination. In the 30-plus years since the Bob Jones decision, the IRS has never threatened such a move against entities that support an all-male priesthood. See Sam Brunson, The Church Will Not Lose Its Tax Exempt Status, By Common Consent (July 9, 2015), https://bycommonconsent. com/2015/07/09/the-church-will-not-lose-its-tax-exempt-status/ (arguing that, in light of longstanding IRS practice, churches that oppose same sex marriage will not jeopardize their tax exempt status). We are by no means recommending a revocation of tax-exempt status for entities that impose gender-based restrictions on ordination, and we think that such a move would indeed raise serious constitutional questions. But we also think that those questions would involve Establishment Clause disabilities on government power to regulate the clergy, not freedom of associational rights applicable to all organizations.

${ }^{205}$ Sager, supra note 197 , at $77-78$.

${ }^{206}$ For reasons of our own, we agree that the Free Exercise Clause does not ordinarily compel religious exemptions from generally applicable norms. See LuPU \& TutTLE, supra note 76, at 195-210.

${ }^{207}$ Sager, supra note 197 , at 78 .

$208 I d$. at 85.

${ }^{209}$ See, e.g., Serbian E. Orthodox Diocese v. Milivojevich, 426 U.S. 696 (1976); Kedroff v. St. Nicholas Cathedral of the Russian Orthodox Church, 344 U.S. 94 (1952). 
have a distinctive meaning for Establishment Clause purposesotherwise, how will we ever explain why a public school may sponsor a daily recitation of "Ode on a Grecian Urn" but not the New York State Regents Prayer; ${ }^{210}$ why the government may build and operate a National Museum of African-American History but not a National Cathedral; or why any particular practice is an establishment of religion?

Having specifically dismissed the true grounds of decision in Hosan$n a$-Tabor, Sager moves on to what he views as the correct explanation for the right of the Catholic Church to insist on an all-male priesthood. The operative norm, he asserts, is the right of "close association." ${ }^{211}$ This right is not limited to religion-based relationships, but extends more broadly to close associations of all kinds. This idea of close association, he writes, finds its paradigm in a dyadic relationship ${ }^{212}$-for examples, the relationship between spouses, priest and penitent, or psychiatrist and patientbut can be extended into group association among congregants, and between congregants and their leaders. The right of close association extends to all groups, including groups like his imaginary Tarpon Bay Women's Blue Water Fishing Club, ${ }^{213}$ which he claims should have the same right as religious groups to choose its "Guides" without interference from the state.

That members of voluntary associations should be free to choose leaders who will reflect the members' deepest concerns is a normatively attractive idea. But it utterly fails to account for what Sager promises to explain-why the Catholic Church can insist on an all-male priesthood. Taken in its totality, the Catholic Church is about as far from a close association as one can get. In its worldwide scope, the Catholic Church has thousands of ordained officials, responsible for everything from supervision of priests to the management of real property and adjudication of disputes arising under canon law. ${ }^{214}$

This quintessentially bureaucratic structure bears no resemblance to the "close associations" that Sager asks us to envision. Members of individual Catholic parishes do not get to choose the priests who perform their rituals and sacraments. ${ }^{215}$ Bishops and others in the hierarchy make those assignments, and the hierarchy is not selected by any form of democratic participation. ${ }^{216}$ Although individual lay Catholics may choose a confessor, or which Masses to attend, these core matters of close associa-

${ }^{210}$ Engel v. Vitale, 370 U.S. 421 (1962).

211 Sager, supra note 197, at 85-89, 97.

${ }^{212} I d$. at 86-87, 99.

${ }^{213} I d$. at 88.

${ }^{214}$ See Frequently Cited Church Statistics, CTr. for Applied Res. Apostolate, http:/ / cara.georgetown.edu/frequently-requested-church-statistics/ (last visited Dec. 20, 2016).

${ }^{215}$ See Canon Law Soc'y of Am., Code of Canon Law (1983) at 840-1165.

${ }^{216} I d$. at $49,139$. 
tion have no direct bearing on employment relationships within the Church. Who is employed as a priest in a particular parish, a bishop in a particular diocese, or an archbishop in a particular archdiocese is a choice made by hierarchical officials, not by an association of equal members of the faith community. The Catholic model is a complete misfit for the supposed principle of close association. Accordingly, Sager's attempt to explain why the Catholic Church is free to discriminate in employment of clergy totally collapses.

Other religious organizations will vary tremendously in the degree of close association they represent. In some faiths, congregations and their members may be actively involved in selecting teachers, preachers of the faith, or other religious leaders. Members of Baptist, Jewish, or Islamic communities, for example, may be heavily involved in selecting their teachers and ministers. ${ }^{217}$ Other faith communities, by organization or size, operate on very different models. Only the most influential members of mega-churches, of the sort led by pastors like Joel Osteen, ${ }^{218}$ will have any voice in the choice of pastor.

Hosanna-Tabor, however, insulates equally every religious community, close association or not, from state supervision in the choice of religious teachers and spokespersons. Sager's attempt to rerationalize the ministerial exception as an illustration of the right of close association cannot possibly be sustained.

Moreover, Sager's "close association" story clashes with the premises of Hosanna-Tabor, which explicitly rejects the government's argument that the Constitution protects secular and religious employers alike. ${ }^{219}$ The Court's version, which rests exclusively on the Religion Clauses, is precisely to the contrary. Nor does Sager's theory readily encompass Cheryl Perich, a teacher who was hired and fired not by the parents and children whom she would teach, but instead by school and church officials. He tries to brush this off as a case at the boundary, ${ }^{220}$ but the awkward fit between Perich's role and Sager's image of close association further undermines his attempt to rerationalize the ministerial exception as an example of close associational rights.

${ }^{217}$ See, e.g., Edward T. Hiscox, The Baptist Church Directory: A Guide to the Doctrines and Discipline, Officers and Ordinances, Principles and Practices of Baptist Churches (1859); Encyclopedia of Islam and the Muslim WORLD (Richard C. Martin ed., 2004).

${ }^{218}$ Osteen is the pastor of Lakewood Church, the largest Protestant congregation in the U.S. He preaches weekly to over 40,000 churchgoers who attend in person, and millions more who watch on television. Joel Osteen, LaKewood CHurch, https://www. lakewoodchurch.com/Pages/new-here/Leadership-Team.aspx (last visited Dec. 20, 2016).

219 Sager, supra note 197 , at 89-90.

${ }^{220}$ Id. at $100-01$. 
Sager's strained effort to cleanse religious specificity from a unanimous decision that bluntly asserts religion specificity is further marred by the damage it would do to principles of nondiscrimination law in other contexts. The Catholic Church is not a close association, but some forprofit business or professional firms might claim-with far more credibility-to be just such an enterprise. Picture a law firm with 20 lawyers, as well as support staff. The lawyers are all Orthodox Jews, or Evangelical Christians, or Sunni Muslims. They subscribe to a set of religious values, and a commitment to daily worship, with which they want to inform their law practice. Accordingly, they insist on hiring only fervent members of their own faith as lawyers, paralegals, and other staff. Should the principle of close association permit this firm to discriminate in employment on the basis of religion? The Supreme Court has never suggested that constitutionally based freedom of association extends to the employment relationship, ${ }^{221}$ and it would betray the profound commitment of the Civil Rights Act of 1964 to permit associational freedoms to impede equal employment opportunity. ${ }^{222}$ Sager's account of the principles beneath the ministerial exception, however, might well do just that. ${ }^{223}$

We understand the impulse to rerationalize Hosanna-Tabor in this way. It is the inevitable product of overstating the Free Exercise dimensions of the case and wholly underappreciating its Establishment Clause roots. Professor Sager's chapter, which spends pages on Smith and the narrative arc of Free Exercise exemptions, ${ }^{224}$ is a prime exemplar of this conceptual mistake. But a right of close association will not get him where he wants to go with religious institutions, and it will take him to places with other entities where we suspect he will flinch at the implications. Hosanna-Tabor is not about a right of close association, and a con-

${ }^{221}$ The Supreme Court's leading cases on the right of expressive association do not involve the employment relationship. See Boy Scouts of Am. v. Dale, 530 U.S. 640 (2000); Hurley v. Irish-Am. Gay, Lesbian, \& Bisexual Grp. of Bos., Inc., 515 U.S. 557 (1995). The ministerial exception of course involves exactly that relationship.

${ }^{222}$ Section 702 of the Civil Rights Act of 1964 (codified at 42 U.S.C. $§ 2000 \mathrm{e}-1$ (2012)) exempts employers with a primary religious purpose from the prohibition on religious discrimination in employment, and the Supreme Court upheld the permissive accommodation reflected in this coreligionist exemption in Corp. of Presiding Bishop of the Church of Jesus Christ of Latter-Day Saints v. Amos, 483 U.S. 327 (1987). But this limited inroad on equal employment opportunity is not constitutionally compelled with respect to nonministerial positions, and in any event is best understood as permitting religious entities, like comparable value-oriented secular entities, to hire only those committed to their cause. The coreligionist exemption has never been extended to for-profit employers. For discussion, see Lupu \& Tuttle, supra note 177 , at 393-94.

${ }^{223}$ He appears to sense this problem without engaging with it. Sager, supra note 197, at 89 (" $[\mathrm{T}]$ he collision between the equality demands and the associational demands of social justice could be extreme, and the pressure ... would cause us to consider more closely the scope and robustness of associational norms.").

${ }^{224}$ Id. at 89-94. 
stitutional right of close association should not extend to the employment relationship. There is no mystery whatsoever why a unanimous Supreme Court rejected the government's attempt to offer an overarching theory of association, secular and religious alike, to explain the legal permissibility of an all-male Catholic priesthood. Professor Sager's theory deserves the same disposition.

\section{The Dissenters-Feminism and the Ministerial Exception}

Over the past 30 years, the most persistent academic critics of the ministerial exemption have been women. ${ }^{225}$ They know that the most common categorical exclusions from the clergy are based on sex. And they also know that ministerial exception cases in U.S. courts frequently involve claims of covert discrimination based on sex. To put it bluntly, in operation the ministerial exception tends to be detrimental to women who are clergy, or teachers in religious schools. This is a matter of regret, and this is why judicial unanimity in favor of Hosanna-Tabor seemed extremely unlikely. How would the religious employer get the votes of Justices Ginsburg, Kagan, and Sotomayor?

Moreover, the arguments that feminist critics of the ministerial exception have advanced over the years are certainly plausible. For example, Professor Corbin's prominent and well-developed work on the subject focused heavily on Smith, and its holding that the Free Exercise Clause does not support religion-based exemptions from generally applicable rules. ${ }^{226}$ Professor Corbin defines very narrowly the class of cases that present ecclesiastical questions, off-limits to courts, as those that involve religious "doctrinal disputes." 227 This leads her to emphasize, along with Smith, the decision in Jones $v$. Wolf, ${ }^{228}$ which teaches that courts may resolve property disputes within a religious community if they can do so using only secular principles of trust, corporate, property, and contract law, and thereby avoid ecclesiastical questions.

Our primary objection to Professor Corbin's view is her apparent willingness to allow courts to adjudicate questions of fitness for ministry.

${ }^{225}$ See, e.g., Robin West, Freedom of the Church and our Endangered Civil Rights: Exiting the Social Contract, in The Rise of Corporate Religious Liberty, supra note 157, at 399; Brant, supra note 24; Corbin, supra note 24; Griffin, supra note 24; Rutherford, supra note 24 . One of the coauthors of this piece originally shared the view that the ministerial exception could not be constitutionally defended, see Ira C. Lupu, Free Exercise Exemption and Religious Institutions: The Case of Employment Discrimination, 67 B.U. L. Rev. 391 (1987), but has since recanted, see Lupu \& Tuttle, supra note 76 , at $90 \mathrm{n} .177$.

${ }^{226}$ Corbin, supra note 24, at 1981-2004 (arguing that Smith undercuts the free exercise basis for the ministerial exception).

${ }^{227} I d$. at 1984-85. Her attempt to force Milivojevich, which involved the question of termination of a high level church official, into this mold is particularly strained.

${ }^{228} 443$ U.S. 595 (1979). 
As we argued in Part III, adjudication of whether an adverse job action is based on ministerial performance or is a pretext for unlawful discrimination will inevitably touch on standards of good ministry. In such cases, the ministerial exception represents an exercise in constitutional prophylaxis, steering courts away from the forbidden territory of adjudicating the quality of ministerial performance and protecting religious employers from adjudicative mistakes.

We recognize that reasonable people can differ about the wisdom of a prophylactic rule in this context. For scholars in the dissenting camp, adjudicative mistakes that permit discriminatory firings are far worse than adjudicative errors that pressure religious entities to tolerate unacceptable performance in ministry. In a world in which the size, frequency, and direction of errors will always be uncertain, the ministerial exception appears to some as a blunt and destructive instrument.

If our disagreement with these scholars were limited to the question of utility with respect to pretext adjudication, we might share their puzzlement about unanimity (though not correctness) in Hosanna-Tabor. But we think there are deeper questions being masked in the terms of the debate, and that highlighting these questions helps to resolve the puzzle. Foremost, we note that recent work by many scholars in this camp does not aggressively challenge the right of religious communities to explicitly discriminate based on sex in determining eligibility for the priesthood. Some steer around the question; ${ }^{229}$ others assert that religious communities may have such a right, as a constitutional ${ }^{230}$ or statutory matter, ${ }^{231}$ but these scholars seek to minimize that right.

${ }^{229}$ Corbin, supra note 24, at 2014, barely mentions the case of overt discrimination, and notes only that it presents no "entanglement" with religious entities because they fully admit what they are doing. See also id. at 2029-31 (suggesting that freedom of expressive association might protect an all-male ministry, but not purporting to resolve the case).

${ }^{230}$ Professor Hamilton's brief in Hosanna-Tabor appears to concede that faith communities may choose to have an all-male ministry. See Brief of Bishopaccountability.org et al. as Amici Curiae in Support of Respondents at 21, Hosanna-Tabor Evangelical Lutheran Church \& Sch. v. EEOC, 565 U.S. 171 (2012) (No. 10-553), 2011 WL 3532696.

${ }^{231}$ Leslie Griffin, The Sins of Hosanna-Tabor, 88 IND. L.J. 981, 1015-16 (2013), suggests that sex might qualify under Title VII as a bona fide occupational qualification (BFOQ) for ministry. But Professor Griffin makes little effort to fit the argument into the narrow legal channels of what counts as a BFOQ; limits her analysis to the Roman Catholic Church; and relies explicitly on an answer to a longdisputed ecclesiastical question of the sort that courts are forbidden to answer. $I d$. at 1017 (citing Catholic authorities for the proposition that "theologically speaking only men can represent Jesus...."). See also Brief of Amici Curiae Law and Religion Professors in Support of Respondents at 30, Hosanna-Tabor Evangelical Lutheran Church \& Sch. v. EEOC, 565 U.S. 171 (2012) (No. 10-553), 2011 WL 3532698 (suggesting that freedom of association might constitutionally protect an explicitly all-male priesthood). 
What might explain this reticence to tackle the core question? Perhaps it is a matter of pragmatic or strategic argument. Explicitly genderbased priesthoods are so deeply embedded in large and ancient faiths that it may seem a kind of folly to challenge those head-on. It seems far easier to argue only that faiths that purport not to discriminate should be held to their word. In such faiths, discrimination against women clergy would have to be hidden behind alternative, pretextual explanations, and adjudication designed to flush out such pretexts becomes a way to force these religious communities to practice the policy of equal employment opportunity that they preach.

On close inspection, however, giving a pass to overt discrimination while attacking the covert variety cannot be defended. If sex discrimination in employment is a moral wrong, deeply at odds with our civil rights tradition, the overt discriminators are by far the graver offenders. This is so as a matter of symbolism, because overt exclusion sends the stark, patriarchal message that women are wholly unqualified for the socially prestigious position of the priesthood. Overt discriminators are also far more harmful as a matter of quantitative impact, because they exclude all women rather than an occasional "troublesome" one. From the state's policy perspective, is it not a far superior outcome that some women may serve in the priesthood of a particular faith than none? It seems odd in the extreme to find liability for the lesser offense of occasional and covert sexism, while ignoring the greater and more damaging offense of blatant exclusion of women.

Two arguments might be advanced in favor of allowing pretext adjudication but not permitting direct legal challenges to explicit disqualification based on sex or other protected characteristics. The first rests on the idea that any religious organization that holds itself out as an equal opportunity employer should be estopped from raising the ministerial exception. The estoppel argument, however, is conceptually flawed. Equal employment policies within religious organizations never take the form of an employer's waiver of legal defenses to a statutory cause of action. Instead, these policies invoke a substantive norm of equal opportunity to which the organization commits itself, without any reference to available legal rights or remedies.

The second argument in favor of adjudication of pretext relies on a policy of incentives for accountability, whereby only those who openly discriminate in hiring receive the benefit of the ministerial exception. This move involves imposition on a religious community of external legal standards-in this context, standards of publicity-for the enterprise of ministry. Recall that the Court describes "the authority to select and control who will minister to the faithful-a matter 'strictly ecclesiasti- 
cal' ... - [as] the church's alone," ${ }^{232}$ without regard to whether the reasons for action qualify as religious. If the boundary imposed by HosannaTabor between the state and the church thus cannot be breached by strong, substantive policy norms against status discrimination, far weaker legal policies involving transparency or accountability should not change the outcome.

The most forceful, frontal attack on the ministerial exception comes from Professor Robin West. In recent work, she has attacked the exception as "a vivid example of a ... deeply troubling family of rights . . 'exit rights." "233 As Professor West eloquently describes the problem, exit rights permit their holders to escape hard-earned and essential elements of the social contract. She includes a number of rights, including the right to bear arms, in the category of exit, but her primary target is the doctrine of freedom of the church, including what West sees as its corollary, the ministerial exception. ${ }^{234}$ To recognize such an exception from laws regulating equality of opportunity, she argues, is "to break faith with and to undermine the shared national project of creating a world of equal opportunity and full participation that is free of racism and sexism and their related effects . . . it is . . both a civic and political breach as well as a moral and contractual wrong." ${ }^{235}$ Nothing in West's bold argument suggests that she would treat overt discrimination as less deserving of condemnation than the covert variety. ${ }^{236}$ Indeed, her premises are most directly implicated by explicit exclusion of women from the priesthood.

West is rightly concerned about the effect of full exit rights for any set of institutions on the longstanding civil rights settlement in favor of inclusion, equal opportunity, and equal respect for all. For these and other reasons, we reject any general notion of freedom of the church. Such a freedom has never been part of our constitutional arrangements. A so-called pluralist doctrine of separate sovereignty represents precisely the claim of exit from the social contract that Professor West decries, with potentially destructive consequences for children and others vulnerable to religious authority, unaccountable to law and democratic processes.

${ }^{232}$ Hosanna-Tabor, 565 U.S. at 195 (citing Kedroff v. St. Nicholas Cathedral of the Russian Orthodox Church, 344 U.S. 94, 119 (1952)).

${ }^{233}$ West, supra note 225, at 402.

${ }^{234}$ Id. at 402-03.

235 Id. at $400-01$.

${ }^{236} I d$. (" $[\mathrm{I}] \mathrm{t}$ is not at all clear why our nation's ministers, rabbis, and imams, whether they are ministering or teaching, should not be drawn from the full and diverse American public rather than one racially or sexually determined segment of it, no less than are our nation's public and private school teachers, police forces, firefighters, professors, healthcare professionals, service providers, and retail, factory, and construction forces. It is even less clear why the churches, synagogues, and mosques that hire and fire them should be explicitly permitted to do so partly on the basis of their race, sex, age, ethnicity, or able-bodied-ness.”). 
Where we part company with Professor West is in linking the ministerial exception to a broad idea of separate sovereignty, or constitutional autonomy, for churches. Our defense of Hosanna-Tabor does not rest on the narrative that she attacks so powerfully. Instead, our position is a reminder that the U.S. has a number of deep and abiding constitutional settlements. Without question, these include the Reconstruction commitment to equal protection, and the statutory embodiments of the egalitarian norms that characterize the late 20th and early 21st centuries. But that commitment does not exclude all prior constitutional settlements. The Reconstruction Amendments must be continuously harmonized with what came before and retains lasting value. For example, reconciling freedom of speech with equality is one prominent context in which American law has engaged in just such an effort to harmonize evolving and cumulative constitutional norms. ${ }^{237}$

Perhaps a less obvious, but equally vital, candidate for this treatment is the longstanding constitutional commitment to a state that maintains its secular character. One key element of that character is the prohibition on state resolution of ecclesiastical questions-among others, the fitness of particular persons for ministry. Excluding the state from regulation of criteria for ministry is inevitably in tension with the norms that Professor West emphasizes. Nevertheless, we think that the ministerial exception, limited to employees engaged in transmission of the faith, appropriately integrates Religion Clause principles with competing normative considerations.

We do not expect Professor West to agree with that judgment, but we hope that she and others who are inclined toward her vision can see that the unanimous opinion in Hosanna-Tabor is not a mysterious, tragic, incoherent, or dangerous move toward subversion of America's egalitarian promise. The decision is far narrower than that. It does not permit religious entities to exit from the social contract. For obvious and important illustration, the decision gives no protection to religious entities that discriminate on legally forbidden grounds (such as sex or race) with respect to nonministerial employees. Furthermore, the state retains the authority to decide which employees are ministerial and which are not.

\section{CONCLUSION}

Hosanna-Tabor commanded the assent of nine Justices who had repeatedly disagreed about a wide variety of other church-state questions.

${ }^{237}$ For broad judicial affirmation of the need to protect expressive freedom, even when it is in tension with norms of equality, see Snyder v. Phelps, 562 U.S. 443 (2011) (holding that First Amendment protects utterers of viciously anti-LGBT speech from liability for intentional infliction of emotional distress), and R.A.V. v. City of St. Paul, 505 U.S. 377 (1992) (invalidating City's hate speech ordinance on its face as content discriminatory). 
Unanimity strongly suggests that this particular controversy did not involve a radical reinterpretation of the Free Exercise Clause; or a bold and hazardous new move with respect to associational freedom; or a stark and sweeping right of exit from egalitarian norms. Instead, Hosanna-Tabor reaffirmed the limited competence of a secular state. That reaffirmation richly deserved the imprimatur of a unanimous Supreme Court. 